\title{
What Are We Speaking About When We Speak About Gender? Gender as a Continuum*
}

\author{
Christel Baltes-Löhr \\ University of Luxembourg, Luxembourg
}

\begin{abstract}
This article shows how, using the figure of the continuum, gender pluralities can be captured in their actually existing diversity and thus be detached from a still powerful and often stereotyping binary constructedness. Gender as a continuum encompasses the four dimensions physical, psychological, social and sexual or: body, feeling, behavior, and desire. It will be demonstrated that all of these dimensions are not clearly separable within themselves and from each other. In the second part of the article, concrete everyday examples and legal debates are discussed from the perspective of the continuum. Thus, we are free to consider differences and similarities between and within the different gender groups in all their diverse shapes and manifestations. The question of what we are speaking about when we are speaking about gender will be answered with a clear "We are speaking about us as individuals and us as a society". The simple reversion of this correlation will lead to the question: "Do we have to speak about gender when we are speaking about ourselves?". This question will be answered with a clear "No", if the normality of plurality and diversity also includes the negation, the absence of gender.
\end{abstract}

Keywords: continuum, plurality, non-binarity, gender, transity, interity

\section{Theoretical Framework of Gender as a Continuum}

Until around 1968, Western European and Anglo-Saxon areas were dominated by a purportedly clear and stereotyping gender order, which differentiated between "female" and "male", which defined the biological "sex" as inherent and unambiguous, ${ }^{1}$ and which connected this order with respective "typically female" and "typically male" canon of feelings and behaviors and a heterosexual structure of desire between man and woman. In this environment, occurrences such as so-called women without ovaries or men without testicles, as well as homoerotic desire including the according social ways of life, and also so-called transgender and intersex persons as well as feelings of so-called women and so-called men that venture beyond the established gender stereotypes were regarded as disruptions, disorders, as sick, deviant, and wrong. At birth, babies are assigned to the female or male gender based on biomorphological characteristics such as vagina or penis. In the

\footnotetext{
*Acknowledgements: My thanks go to Svantje Volkens for her support by translating this text and the accompanying discussions as well as to Laura Löhr for her hint about Figures 10,11, and 18.

This article is based on a lecture, held as a part of the 4th Transatlantic Dialogue "Creating Human Bonds through Cultural Diplomacy", organized by François Carbon, University of Luxembourg, and held in Luxembourg, 24-26, May 2017.

Christel Baltes-Löhr, Professor, Faculty of Language and Literature, Humanities, Arts and Education, University of Luxembourg.

1 Towards the end of the 18th century, in the course of Enlightenment, the notion of a natural, bipolar sex/gender order of man and woman superseded the medieval belief of god-given genders that had dominated European discourse until this point; see: Sigrid Schade/Monika Wagner/Sigrid Weigel (1994): "Zur Einführung". In: Id. (ed.): Allegorien und Geschlechterdifferenz. Cologne: Böhlau, pp. 1-7.
} 
case of ambiguous sexual characteristics, for example an undersized penis or an oversized clitoris, so-called feminizing or masculinizing surgeries have in the past been, and to this day still frequently are, performed on healthy newborns. Based on their sexual characteristics, certain feelings and behaviors, as well as the orientation of their sexual desires towards the respective other gender, were expected from so-called girls/women and boys/men. Heteronormativity was regarded as predominant.

Since the second half of the 20th century, women's and gay rights movements have increasingly questioned the gender binary ${ }^{2}$ and discussed the oppressive effects of a heteronormative order. ${ }^{3}$ Nonetheless, gender was still regarded as the structural category of human forms of life. Only with the arrival of notions of intersectionality, ${ }^{4}$ which illustrated belonging to an ethnicity and a social class as axes of difference next to gender, gender was discussed in more complex contexts. Especially with the insights into the constructedness of gender and gender relations by way of performative processes, repetitions, and subversions, which were expounded by Judith Butler, ${ }^{5}$ new perspectives were introduced and gender was detached from a heteronormative approach. According to Butler, a performative action is "one which produces or stages that what it names." Repetitions become significant, and with them subversive shifts of meaning which then become possible. In this way distinctions and differences, but also similarities can be represented, in the full knowledge that a performative action, a performative act, and the concomitant descriptions and definitions can never claim to represent the entire subject or the subject in its supposedly correct or indeed true meaning. Purported originals that existed prior to the performative act are negated. The performative repetition always refers to a something, which is considered different. Important is thus the notion of continuously ongoing differentiation processes, which Derrida denotes with the term "différance", in order to say "that every meaning can only ever be expressed within a deferral, a delay, a deliberation or a retrospect." ${ }^{, 7}$ Following Deleuze, ${ }^{8}$ it should also be assumed that repetition can never be repetition of the same, because the repeated elements cannot be encompassed by a term common to all of them as an origin. Repetition is to be seen as a repetition of the not-same, the non-identical, and the diverse. This view of repetition corresponds to the diverse subject. "The subject of the eternal recurrence is not the same, but the different, not the similar, but the dissimilar, not the one but the many, not the necessity but the coincidence." ${ }^{9}$ We could add: There is no origin from which

\footnotetext{
2 German: "Zweigeschlechtlichkeit".

3 Andrea Maihofer (1995): Geschlecht als Existenzweise. Frankfurt/Main: Ulrike Helmer; Regina Becker-Schmidt (1993): "Geschlechterdifferenz-Geschlechterverhältnis: soziale Dimensionen des Begriffs 'Geschlecht"”. In: Zeitschrift für Frauenforschung, 1/2, pp. 37-46.

${ }^{4}$ Gudrun-Axeli Knapp with reference to Kimberlé, who, based on analyses of court proceedings, indicated the significance of race and class beside the category of gender; Kimberlé Crenshaw (1991): "Mapping the Margins: Intersectionality, Identity Politics, and Violence against Women of Color". In: Stanford Law Review, vol. 43, no. 6, pp. 1241-1299; Gudrun-Axeli Knapp (2005): “'Intersectionality' - ein neues Paradigma feministischer Theorie? Zur transatlantischen Reise von 'Race, Class, Gender'”. In: Feministische Studien, no. 1, pp. 68-81.

5 Judith Butler (1991): Das Unbehagen der Geschlechter. Frankfurt/Main: Suhrkamp; Judith Butler (1993): "Für ein sorgfältiges Lesen”. In: Seyla Benhabib et al. (ed.): Der Streit um Differenz. Frankfurt/Main: Suhrkamp, pp. 123-132; Judith Butler (1995): Körper von Gewicht. Die diskursiven Grenzen des Geschlechts. Frankfurt/Main: Suhrkamp.

${ }^{6}$ Butler 1993, p. 123.

7 Personal translation of: "Dass jeglicher Sinn immer nur in einem Aufschub, einer Verzögerung, einem Kalkül oder einer Nachträglichkeit zum Ausdruck kommen kann."; Derrida quoted by Jörg Zirfas (2001): "Identitäten und Dekonstruktionen. Pädagogische Überlegungen im Anschluss an Jacques Derrida”. In: Anja Tervooren/Jutta Hartmann/Bettina Fritzsche/Andres Schmidt (ed.): Dekonstruktive Pädagogik. Wiesbaden: Springer, pp. 49-64, here p. 55.

${ }^{8}$ Gilles Deleuze (1968): Différence et Répétition. Paris: PUF.

9 Personal translation of: "Das Subjekt der ewigen Wiederkehr ist nicht das Selbe, sondern das Differente, nicht das Ähnliche, sondern das Unähnliche, nicht das Eine sondern das Viele, nicht die Notwendigkeit, sondern der Zufall.”; Peter V. Zima (1997): Moderne/Postmoderne. Gesellschaft, Philosophie, Literatur. Stuttgart: UTB, p. 169, in reference to Deleuze, Vattimo, Lyotard.
} 
differentiations could be derived, the subject is not that which is confined, but rather that which is not defined within its confines. However, these performative repetitions harbor possibilities to bring forth multiple new aspects of a subject, so that dually and dichotomically arranged hierarchies can change, shift, dissolve, but also stabilize themselves. In this sense, repetition can have a de-homogenizing and heterogenizing effect, can make space for plurality and differences, and at the same time bring out similarities or reject them. The new is thus always created in relation to something, mostly to what is old, traditional, known. The new emerges within slowly shifting changes. The now is passing or passed in the moment of its "existence". The new now, which is conceived in the future, is now already the past now of just a moment ago.

With a theoretical toolbox such as this, the concept of gender as a continuum can analytically re-envision and re-illuminate actually existing pluralities, variations and diversities, differences and similarities of gender on a societal and individual level.

\section{The Figure of Gender as a Continuum}

This figure originated in $2014,{ }^{10}$ in the examination of the question of how so-called transgender and so-called intersex can be regarded not as a "third" or "other" or "hybrid" gender, and not as a new pair of opposites, since transsexuality/transgender experiences are still mostly seen as situated in the area of "not feeling at home" in one's own body, ${ }^{11}$ and intersexuality ${ }^{12}$ is more likely associated with bodily characteristics such as the size of the penis and the clitoris, the structure of the vagina, the position of the testicles, the presence of ovaries and uterus, sets of chromosomes and hormone levels of testosterone and estrogen. Bipolar opposites such as this can be overcome using the figure of the continuum, since differences and similarities between trans and inter persons, ${ }^{13}$ as well as between so-called women and so-called men, are evaluated. Based on this, all possible, presently established and still unestablished genders can ultimately be situated within an equal and equitable relationship to each other. Thus, depending on the historical situation, cultural context and individual or societal configuration, each gender can be regarded as the first gender. In this model, so-called transsexuality and so-called transgender, here newly named as transity and interity, ${ }^{14}$ are no longer considered as located between the two so-called main poles "femininity" and "masculinity", no longer considered a new "pair of opposites" of an extended, but nonetheless bipolar gender order, but are regarded as situated on a continuum. "Femininity" and "masculinity", as well, could be captured in their actual diversity in respect to their physical and emotional dimensions, to social behaviors and sexual desires. If not all so-called women experience themselves as "feminine" with homogenous intensity, and if not all of them act according to the still prevalent stereotype settings, then the same is to be assumed for so-called men and, it has to be emphasized

\footnotetext{
${ }^{10}$ Christel Baltes-Löhr (2015): "Immer wieder Geschlecht-immer wieder anders. Versuch einer Begriffserklärung”. In Erik Schneider /Christel Baltes-Löhr (ed.): Normierte Kinder. Effekte der Geschlechternormativität auf Kindheit und Adoleszenz. Bielefeld: transcript, pp. 17-40; Christel Baltes-Löhr (2018a): “Always Gender-Always Different. An attempt at a definition”. In: Erik Schneider/Christel Baltes-Löhr (ed.): Normed Children. Effects of Gender and Sex Related Normativity on Childhood and Adolescence. Bielefeld: transcript, forthcoming; Christel Baltes-Löhr (2016a): "Geschlecht als Kontinuum-Pluralität als Existenzmuster. Gender as a continuum-Plurality as Pattern of Existence. Gender ca proces continuu - pluralitatea ca model de existență”. In: Studia Universitatis Babeş-Bolyai. Philologia 4, vol. 61/2016, pp. 21-36; Christel Baltes-Löhr (2018b): Geschlecht als Kontinuum. Zur Pluralität gelebter Realitäten. Bielefeld: transcript, forthcoming.

11 Anne Allex (2012) (ed.): Stop Trans*-Pathologisierung. Neu-Ulm: AG SPAK, p. 15.

12 Ibidem, p. 14.

${ }^{13}$ In this article the differentiation between transgender and intersex is replaced by the terms trans and inter persons.

14 These new terms "transity" and "interity" are used in equivalence to femininity and masculinity and in order to avoid the purported proximity of trans to gender identity and inter to sexuality; German: transity: Transgeschlechtlichkeit and interity: Intergeschlechtlichkeit.
} 
again and again, for all other established and unestablished gender groups. A concept of gender(s) such as this, which oversteps currently prevalent and new bipolarities, is described within the framework of the figure of the continuum by the term "polypolarity".

If the figure of the continuum can be used to detach gender from a binary positioning, then, speaking more broadly, the figure of the continuum also replaces the figure of the Third, the In-between and the Third Space. The figure of the continuum, which incidentally can not only be shown for gender, but also for migration, culture, space, time, health, age, and memories. ${ }^{15}$ Gender as a continuum constitutes a model of thought which is able to portray all existing and thinkable differences, which are always to be regarded as fluid, and all, equally fluid, similarities within individual gender groups and between the genders in such a way that actually existing forms of life in all their diversity no longer need to fall victim to restrictive categorial orders and the often connected hierarchies of 1st, 2nd, 3rd, 4th or more genders. Gender as a continuum in a way provides a conceptional space for changes within an individual biographical course of life regarding the association with, or the assignment to, a gender, and provides space for different positionings depending on the situational, but also the cultural context in a specific phase of life, either for a single individual or for a group of individuals. Further, historical changes of notions of gender and gender orders, with all their variabilities, differences, and similarities, can be depicted and analyzed using the figure of the continuum.

\section{Horizontal and Vertical Shapes of the Continuum-Ambiguities and Variabilities}

Within the concept of "gender as a continuum", the four dimensions of the physical, the psychological, the social, and the sexual, which will be explained in more detail later in the text, are distinguished and simultaneously combined. The physical dimension signifies the corporal, biological gender (frequently labeled "sex"), the psychological dimension signifies the felt gender (frequently labeled "gender identity"), the social dimension signifies the social gender (frequently labeled "gender"/behavior according to gender), and the sexual dimension signifies the sexual gender (frequently labeled "sexual desire/sexual orientation"). All of these dimensions, within themselves and in their relation to one another, are regarded as not definitively separable. We can speak of a horizontal shape of the continuum if one is analyzing the variations of one of the four dimensions. Distinct from this is the vertical shape of the continuum, which signifies the interwovenness and the interactions between the dimensions, with all the resulting variations. Thus, the transitions between the physical, psychological, social, and sexual dimensions are to be understood as porous and permeable.

In practice, this can mean that not all so-called women with a vagina also possess a wide pelvis, narrow shoulders and/or ovaries, just as so-called men with a penis do not always have a flat chest and a narrow pelvis. The experienced gender, as well, can feature very differently for individual persons, and can change multiple

\footnotetext{
${ }^{15}$ Christel Baltes-Löhr (2016b): "Die Figur des Kontinuums am Beispiel von Geschlecht und Migration. Ein Erklärungsansatz für Pluralitäten als Existenzmuster?”. In: Raluca Rădulescu /Christel Baltes-Löhr (ed.): Pluralität als Existenzmuster. Interdisziplinäre Perspektiven auf die deutschsprachige Migrationsliteratur. Bielefeld: transcript, pp. 9-29; Christel Baltes-Löhr (2016c): "Geschlecht, Migration und Raum als Kontinuum. Versuch einer Begriffsbestimmung. Gender, migration and space as a continuum. Attempt of a definition”. In: Germanistische Beiträge, 39/2016, Sibiu/Hermannstadt: Universitätsverlag, pp. 74-98; Christel Baltes-Löhr (2017): "Die Figur des Kontinuums als Analyseraster fü $\mathrm{r}$ Geschlecht in Literatur, Alltag und Geschichte - ein Versuch". In: Puchianu, Carmen Elisabeth (ed.): Konstruktionen von Männlichkeit und Weiblichkeit in der deutschen Kultur, Literatur und Sprache. Reihe Academica. Kronstädter Beiträge zur germanistischen Forschung, vol. 17, Kronstadt/Braşov: Aldus, pp. 9-33; Christel Baltes-Löhr (2018c): "Geschlecht, Wanderungen, Erinnerungen, Identitätskonstruktionen - ausgeleuchtet mit der Figur des Kontinuums”. In: Christel Baltes-Löhr/Beate Petra Kory/Gabriela Sandor (ed.): Auswanderung und Identität. Erfahrungen von Exil, Flucht und Migration in der deutschsprachigen Literatur. Bielefeld: transcript, forthcoming.
} 
times over the course of a life, so that people do not always or equally feel female, male, trans, or inter in any given situation. Not all women, men, trans, or inter persons show a similar or homogenous behavior in the social dimension of gender as other persons belonging to the same gender group. Likewise, sexual desire, sexual orientations, and sexual practices overstep heterosexuality between women and men. Monosexual, asexual, bisexual, homosexual, pansexual, and heterosexual structures and practices of desire are manifest, which cannot necessarily be derived from the affiliation to a specific gender or a specific gender group. This should, at this point, suffice to briefly describe the continuum in its horizontal shape.

The vertical shape of "gender as a continuum" means that the four dimensions are not to be regarded as being in an unambiguous relation to each other, as the still prevalent notions of stereotypical femininity and masculinity would lead one to believe. Frequently, one still encounters the descriptors of a "real/right" girl/woman or a "real/right" boy/man. Vertical shape of "gender as a continuum" means, more concretely, that the positioning of an individual person within the four dimensions may shift continuously, and that a person, at a specific point in their life, may exhibit a gender-specific behavior, which by all means corresponds to notions of a "real/right" girl, but who exhibits male physical sexual characteristics, often feels oft as a girl and wants to enter first erotic relationships with a person, who is biomorphologically and chromosomally male, has internal testes, and feels erotically drawn to so-called girls and so-called boys. ${ }^{16}$

At this point, the complexity of possibilities of gender attributions and imaginable gender relations is made abundantly clear, especially if one also considers that these positionings can indeed change or shift more or less profoundly over the course of a life. The complexity becomes even more evident if all the processes of external and self-assignments of gender are considered. This also means that the concept of what, for example, is societally connoted as a certain gender can vary, and it means that what is understood as a self-assignment of "female", "male", "trans", or "inter" can have very different shapes. The concept of "gender as a continuum" opens spaces for the recognition of actually lived and existing diversities and complexities of forms of gender, space for changes and shifts between the genders as well as space for the multitude of reasons for belonging or not belonging to a gender. "Gender as a continuum" can thus facilitate the "breaching of hitherto often restricting gender categories" $" 17$ or even indicate their unraveling. Gender, in the second half of the 20th century proclaimed as the structural category of human forms of life,$^{18}$ on both a societal and an individual level, increasingly seems to be regarded with its actually existing variations and diversities, raising the question of the extent to which this category, with its seemingly clear connotations, is in the process of shifting or even unravelling.

\section{The Four Dimensions of Gender as a Continuum-Overstepping Heteronormativity}

\section{Physical Dimension of Gender as a Continuum}

Until the 1980s, the following order was considered natural. The so-called biological gender, often termed "sex", was regarded as unambiguous, as clear.

\footnotetext{
${ }^{16}$ Noteworthy in this context: The film by Alain Berliner "Ma vie en rose" (1997), Belgium; Anett Heide (2018): "Intersexualität: Hallo, ich bin die dritte Option". In: Zeit online, 01/24/2018, http://www.zeit.de/zeit-magazin/leben/2018-01/intersexualitaet-geschlecht-intergeschlechtlichkeit-identitaet, last accessed: $1 / 27 / 2018$.

${ }^{17}$ Personal translation of: "Durchbrechen bislang oftmals einengender Geschlechterkategorien"; Ainhoa Achutegui (2014): "Jeder Tag Weltfrauentag". In: Luxemburger Wort, 03/08/2014, p. 3.

18 Maihofer 1995; Becker-Schmidt 1993.
} 


\begin{tabular}{|c|c|c|}
\hline & female & male \\
\hline Morphological & $\begin{array}{l}\text { Vagina } \\
\text { Projecting breasts } \\
\text { Narrow shoulders } \\
\text { Wide pelvis/hips } \\
\text { No facial hair }\end{array}$ & $\begin{array}{l}\text { Penis } \\
\text { Flat breast } \\
\text { Broad shoulders } \\
\text { Narrow hips } \\
\text { Beard growth }\end{array}$ \\
\hline Chromosomal & $\mathrm{xx}$ & xy \\
\hline Gonadal & Ovaries & Testicles \\
\hline Hormonal & Estrogen & Testosterone \\
\hline
\end{tabular}

Figure 1. So-called biological sex, supposedly unambiguous and clearly distinguishable.

However, insights from biological research have made it obvious since the 1980s that the so-called biological "sex" cannot be unambiguously defined, as was assumed for a long time. ${ }^{19}$ According to Streckeisen, the following identification features can be distinguished from a somatic-physical viewpoint: chromosomes, gonads, morphology, and hormones. ${ }^{20}$ If the biological "sex" were clearly definable, then all persons with a vagina, as adults and adolescents, would have to possess an elevated bosom as well as ovaries, a similar estrogen concentration, and the same set of XX chromosomes. On the other side, the XY chromosome would always have to entail a penis, testes, and a corresponding testosterone level. All so-called women would, for example, have to possess a vagina, ovaries, uterus, elevated breasts, narrow shoulders, a wide pelvis, and no facial hair except for eyelashes and eyebrows. Morphologically, using this same, allegedly unambiguous attribution, men would have a penis, external testes, a flat chest, wide shoulders, narrow hips, and facial hair in addition to eyelashes and eyebrows. This, however, is not the case. There exists a variance in the combination of the different components, meaning that one can no longer speak of a biologically unambiguous assignment of genders. ${ }^{21}$ In reality, not all women with a vagina have a wide pelvis or ovaries. Men with a penis, as well, can possess ovaries and/or more or less elevated breasts. The hormones testosterone and estrogen can vary strongly in persons who potentially fit the morphological female or male criteria. Facial hair in women is a topic that can be discussed for hours and which fills magazines and beauty parlors, as well as, by now, sparse facial hair in men, not to mention pubic hair.

This allows the first conclusion that the biological "sex" is not unambiguously definable.

\section{Psychological Dimension of Gender as a Continuum}

On the level of feelings, in the psychological dimension of gender as a continuum, frequently called gender identity, the unambiguity of the binary order "female-male" has started to waver as well. The psychological dimension of gender describes the feeling as well as the self-awareness of gender and thus oscillates between assignment and appropriation, between external and internal attribution, and results in self-denominations, which coincide more or less with denominations by others. In this way, so-called women do not always and not in every situation experience themselves as "female", and conversely so-called men do

\footnotetext{
${ }^{19}$ Ursula Streckeisen (1991): Statusübergänge im weiblichen Lebenslauf. Frankfurt/Main and New York: Campus, p. 158; Winfried Henke/Hartmut Rothe (1998): "Biologische Grundlagen der Geschlechtsdifferenzierung". In: Auffermann, Bärbel/Weniger, Gerd-Christian (ed.): Frauen—Zeiten-Spuren. Mettmann: Neanderthal-Museum, pp. 43-64.

${ }^{20}$ Streckeisen 1991, p. 158.

${ }^{21}$ Henke et al. 1998, pp. 43-64.
} 
not always and not in every situation experience themselves as "male". Likewise, additional attributions and experiences beyond the categories "female" and "male" are manifest, as for example so-called self-perceptions and attributions of trans and inter persons. People may identify with a gender, identify with no gender, identify with the gender that was assigned to them at birth, not identify with the gender assigned to them at birth, identify with multiple genders simultaneously, identify with multiple genders based on the situation, comply with the attributions of feelings and experiences of one gender - or not, identify with a gender but not the corresponding stereotypical assumptions, not identify with any gender.

This leads us to the second conclusion that, regarding the psychological dimension of gender as a continuum as well, we can no longer assume an unambiguous definition along the borders of "female" and "male".

\section{Social Dimension of Gender as a Continuum}

This dimension is described in more detail, since the question of what constitutes "female" and "male", based on the so-called physical traits at birth, is principally connected to the social behavior and to the fundamental features, which are assumed to be resulting from this behavior. Proceeding from stereotypical attributions of behaviors to so-called women and so-called men, which are based on the assumption of a gender binary, the following stereotypes have been until the late 1960s - and partly still to this day are-rarely questioned. Girls and women are expected to be emotional, passive, empathetic, gentle, natural, related to the body, and dependent, whereas boys and men seem to be characterized by rationality, activity, hardness, strength, culture, mind, and autonomy. Other genders have, despite the vehement atmosphere of departure in the 1960s in the context of women's movements, rarely been spoken about until the 1990s. These binary attributions of stereotyping gender behaviors were defined antagonistically, meaning oppositional to each other, and could thus not be exchanged. The characteristics and behaviors attributed to boys and men were considered superior, which is expressed in Figure 2.

\begin{tabular}{|l|l|}
\hline Gender-related, binary stereotypes_late 1960s & Male \\
\hline Female & Rational \\
\hline Emotional & Active \\
Passive & Strong \\
Sensitive & Hard \\
Soft & Related to culture \\
Related to nature & Mind \\
Body & Autonomous \\
Dependent & \\
\hline
\end{tabular}

Figure 2. Gender-related, binary stereotypes-late 1960s.

From the late 1960s onward, the women's movement brought about two important normative shifts in the Western European and Anglo-Saxon areas. The normative coin flipped, femininity and the connected stereotypes moved to the front and were normatively revalued, as Figure 3 tries to show.

\begin{tabular}{|l|l|}
\hline Gender-related, binary stereotypes_-first paradigmatic change-_ince 1975 \\
\hline Female & Male \\
\hline Emotional & Rational \\
Passive & Active \\
Sensitive & Strong \\
Soft & Hard \\
Related to nature & Related to culture \\
Body & Mind \\
Dependent & Autonomous \\
\hline
\end{tabular}

Figure 3. Gender-related, binary stereotypes—first paradigmatic change-since 1975. 
With insight into existing differences between women and between men the notion took hold that there was no innate female or innate male nature. Gender-related social behavior was considered the result of social construction processes. The normative coin flipped once again. To the forefront came plurality.

\begin{tabular}{|c|}
\hline Gender as plurality, overstepping binary stereotypes - second paradigmatic change - since 1995 \\
\hline ....unknown...female......male......unknown ......male......inter ....... trans......female....inter.... unknown....trans \\
all genders \\
can become \\
emotional, rational, passive, active, empathetic, hard, soft, strong, \\
connected to nature and culture, related to the body, \\
intellectual, dependent, autonomous, capable of relationships, incapable of relationships etc.
\end{tabular}

Figure 4. Gender as plurality, overstepping binary stereotypes—second paradigmatic change—since 1995.

It became evident that members of all gender groups could become and be emotional, rational, passive, active, empathetic, hard, soft, strong, connected to nature and culture, related to the body, intellectual, dependent, autonomous, capable of relationships, incapable of relationships etc., if they-and this is crucial at this juncture - are given opportunities over the course of their lives to develop their abilities - beyond established binary gender boundaries.

This leads us to the third conclusion that gender-related behaviors and characteristics should be regarded as plural and diverse.

\section{Sexual Dimension of Gender as a Continuum}

If the sexual dimension of gender as a continuum encompasses sexuality, sexual desire, and sexual orientation, then the well-trodden matrix of binary heterosexuality that locates sexual desire between men and women has been overtaken, or overridden, by existing pluralities. In addition to heterosexual orientations and structures of desire, monosexual, asexual, bisexual, homosexual, pansexual desire manifests itself. Social life partnerships such as marriage and family are no longer solely based on heteronormative notions like a life-long monogamous marriage between a woman and a man. Homosocial forms of life that are based on structures of desire between members of the same gender category are being accepted in an increasing number of societies, and are being treated as equal to the heteronormative marriage between a woman and a man in a legal context as well. ${ }^{22}$ It cannot be expected that trans and inter persons can be attributed to just one respective specific form of sexual desire.

This allows the fourth conclusion that sexual desire and sexual orientations can no longer be depicted by a binary heterosexual matrix.

\footnotetext{
${ }^{22}$ For the current situation see: http://www.faz.net/aktuell/feuilleton/debatten/diskussion-zu-homo-ehe-gesetz-2016-indeutschland-14167436-p3.html; http://de.wikipedia.org/wiki/Gleichgeschlechtliche_Ehe; Tomasz Kitliński/Pawel Leszkowicz (2013): "Bipolar. Homophobie und Toleranz in Polen." In: Osteuropa, no. 10, pp. 195-239; www.spiegel.de/politik/ausland/frankreich-randale-nach-grossdemo-gegen-homo-ehe-a-902001.htm; Éric Fassin (2015): "Die Kunst, nicht so sehr kategorisiert zu werden. Eine Kritik des Wissens und der Macht des Geschlechts”. In: Erik Schneider/Christel Baltes-Löhr (ed.): Normierte Kinder. Effekte der Geschlechternormativität auf Kindheit und Adoleszenz. Bielefeld: transcript, pp. 87-104; Éric Fassin (2018): "The art of not being categorized quite so (much). A Critique of the Knowledge and Power of Sex". In: Erik Schneider /Christel Baltes-Löhr (ed.): Normed Children. Effects of Gender and Sex Related Normativity on Childhood and Adolescence. Bielefeld: transcript, forthcoming.
} 


\section{First Review}

Every gender category "female", "male", "trans", "inter" as well as hitherto unknown and unnamed genders consists of the four dimensions - physical, psychological, social, and sexual or: body, feeling, behavior, and desire. The transitions within each of the four dimensions are fluid, which is to be understood as the horizontal shape of the continuum, or as intradimensional variability. The relation of the four dimensions of gender to one another is likewise not clearly definable, which is to be regarded as the vertical shape of the continuum, or as interdimensional variability. Depending on the situational context, in one female, male, inter or trans person, one or another dimension of gender may in one specific situation stand out more dominantly, and play a more or less important role for the respective person. Shifts within and between the individual dimensions may vary depending on time, space, cultural context, and biographical life periods. This can be supposed for all hitherto known and named, as well as for all hitherto unknown and unnamed, genders.

\begin{tabular}{|c|c|c|c|}
\hline \multicolumn{4}{|c|}{ Figure of the continuum } \\
\hline \multicolumn{4}{|c|}{ Sex/gender } \\
\hline \multicolumn{4}{|c|}{ Hitherto known and named forms/categories of gender } \\
\hline Transity & terity & Masculinity & Femininity \\
\hline \multicolumn{4}{|c|}{$\begin{array}{l}\text { Hitherto unused definitions } \\
\text { Examples }\end{array}$} \\
\hline Physical/corporeality/matter & $\begin{array}{l}\text { Biolo } \\
\text { Exam } \\
\text { Amb }\end{array}$ & physical traits & \\
\hline Psychological/feeling/experience & $\begin{array}{l}\text { Expe } \\
\text { Exan } \\
\text { Self- } \\
\text { Situa }\end{array}$ & $\begin{array}{l}\text { er identity } \\
\text { nent by others; } \\
\text { nment of a ger }\end{array}$ & ssignment \\
\hline Social/behavior & $\begin{array}{l}\text { Socia } \\
\text { Exam } \\
\text { Girls } \\
\text { these } \\
\text { Trans }\end{array}$ & n do not behav & $\begin{array}{l}\text { tereotypes ascribed to } \\
\text { binary stereotypes }\end{array}$ \\
\hline Sexual/desire & $\begin{array}{l}\text { Sexu } \\
\text { Exam } \\
\text { Sexu } \\
\text { them }\end{array}$ & $\begin{array}{l}\text { xual orientatic } \\
\text { within the patt }\end{array}$ & $\begin{array}{l}\text { lationships based on } \\
\text { al structure of desire }\end{array}$ \\
\hline \multicolumn{4}{|c|}{$\begin{array}{l}\text { Boundaries and unambiguities shift } \\
\text { within the respective dimensions (horizontal, intradimensional variability) } \\
\text { between the respective dimensions (vertical, interdimensional variability) }\end{array}$} \\
\hline \multicolumn{4}{|c|}{$\begin{array}{l}\text { Polypolarities } \\
\text { Positionings of genders can exist beyond the two poles of "femininity" and "masculinity". } \\
\text { Within one gender category, one or another dimension, at a specific point in time, in a specific situation and/or in a specific } \\
\text { cultural context, may become more or less relevant }\end{array}$} \\
\hline \multicolumn{4}{|c|}{$\begin{array}{c}\text { Diachronic, biographical and cultural variabilities and polypolarities } \\
\text { The complexity of gender as a continuum may vary depending on personal age and contemporary history, as well as on cultural } \\
\text { settings }\end{array}$} \\
\hline \multicolumn{4}{|c|}{$\begin{array}{l}\text { Gender as a continuum } \\
\text { is always embedded in an intersectional perspective } \\
\text { of importance are age, cultural/ethnic origin, socio-economic status, social environment, religious and political convictions }\end{array}$} \\
\hline conduce & & $\begin{array}{l}\text { nuum experienced } \\
\text { l }\end{array}$ & \\
\hline
\end{tabular}

Figure 5. Tabular overview of "Gender as a Continuum". 


\section{Resistant Remnants? Ongoing Stereotypes and Discriminations}

In spite of a powerful women's movement in the Western European and Anglo-Saxon area from 1968 onwards, stereotyping assumptions of gender can still be found in practical everyday life; this circumstance will in the following be demonstrated using a number of images, and discussed within the context of the concept of "gender as a continuum".

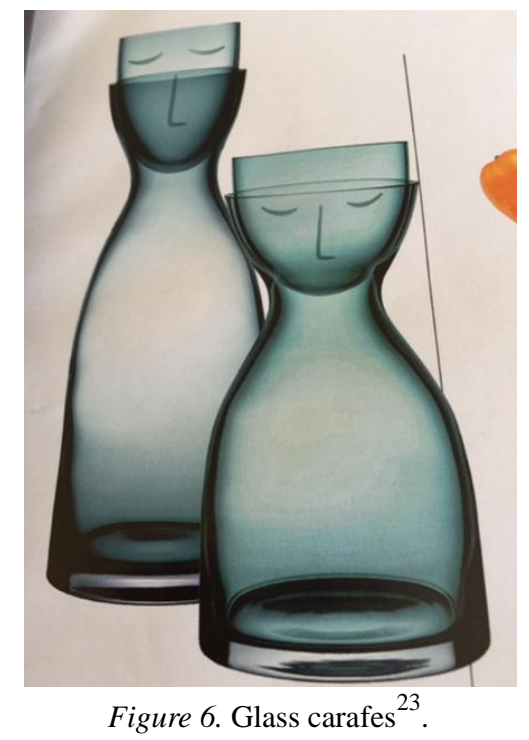

The accompanying text reads: “... showing face. Nicer than drab water bottles on the nightstand: the water carafes 'Mr. \& Mrs.' with drinking glass lids have been designed especially for quenching your midnight thirst. Almost too good for just the bedroom. Nude, 24 and $20 \mathrm{~cm}$ in height, 72 Euros each., ${ }^{, 4}$ One can easily spot feminine and masculine shapes in the glass faces and bodies.

This image thus principally conjures up morphological aspects of the physical dimension of gender as a continuum: the more slenderly shaped carafe on the left side of the image, which is connoted in a masculine way, is four centimeters higher than the feminine, more rounded counterpart. The positioning of the carafes in the image once again emphasizes the differing height, which may evoke the association of the male guardian; this speaks to the social dimension of gender as a continuum. A noteworthy connection between biomorphology (physical dimension) and attribution of traits (social dimension) emerges in the more stocky, round shape of the drinking glass lid of the carafe pictured on the right, especially in the lower half of the lid, which may bring to mind a gentle, feminine smile. The "male", or masculine-connoted drinking glass lid, in contrast, seems somewhat more taut and rational, and appears less emotional. Equal for both versions, besides the material, is merely the price, which is fairly hefty in comparison to ordinary, "drab" water bottles.

In a completely different instance, the traffic signs 133 and 123 of the current warning signs as per Addendum 1 to $§ 40$ StVO Strassenverkehrsordnung (German traffic regulations) show the following:

\footnotetext{
23 Donna, 3/2016, 9.

${ }^{24}$ Ibidem.
} 


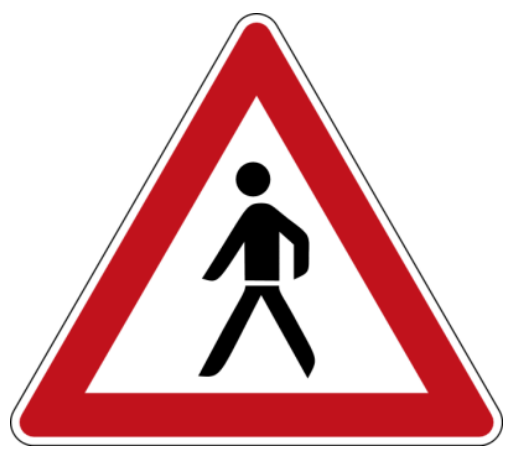

Figure 7. Pedestrian ${ }^{25}$.

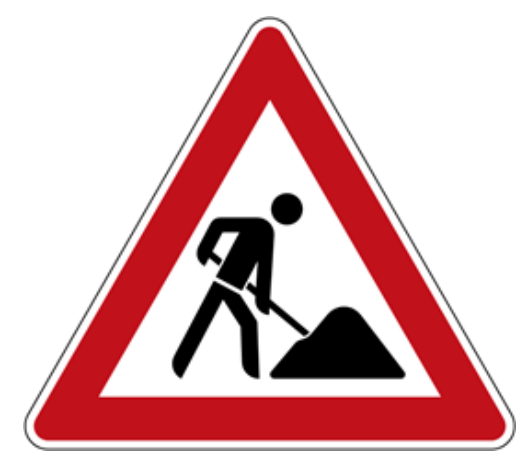

Figure 8. Road Work Ahead ${ }^{26}$.

The sign Fig. 7 carries the title Pedestrian, and is intended to urge all traffic participants for caution regarding persons who are moving in or along the road on foot. Similarly as on the warning sign Caution: Road Work Ahead, the figural depictions of these pictograms are clearly marked as male-connoted pedestrians and road workers. In this context, as well, clear stereotyping attributions regarding the social dimension of gender as a continuum are discernable: the public space, the road, is evidently populated by men; women or even other genders do not appear here or in the depiction of the often difficult physical labor on construction sites. Female construction workers have so far been sequestered to the realms of fiction or art, as shown in the exhibition iLux. Identitéiten zu Lëtzebuerg / Identités au Luxembourg / Identitäten in Luxemburg (Identities in Luxembourg; July 2012-June 2013) ${ }^{27}$ by curators Prof. Dr. Sonja Kmec and Dr. Gianna Thommes, both of the University of Luxembourg.

25 Gefahrzeichen 133 as per Addendum 1 to $\S 40$ StVO Strassenverkehrsordnung (StVO); https://de.wikipedia.org/wiki/Bildtafel_der_Verkehrszeichen_in_der_Bundesrepublik_Deutschland_seit_2013, last accessed on 03/12/2018.

26 Gefahrzeichen 123 as per Addendum 1 to $\S 40$ StVO Strassenverkehrsordnung (StVO); https://de.wikipedia.org/wiki/Bildtafel_der_Verkehrszeichen_in_der_Bundesrepublik_Deutschland_seit_2013, last accessed on 03/12/2018.

27 Research unit IPSE of the University of Luxembourg (2012) (ed.): Katalog zur Ausstellung: iLux. Identitéiten zu Lëtzebuerg/Identités au Luxembourg/Identitäten in Luxemburg. Editorial team: Kmec Sonja/Thommes, Gianna, Luxemburg; http://wwwde.uni.lu/forschung/flshase/identites_politiques_societes_espaces_ipse/research_instituts/institute_for_history/recherch e/projet_de_recherche/ilux_identaeten_in_luxemburg, last accessed on 03/12/2018. 


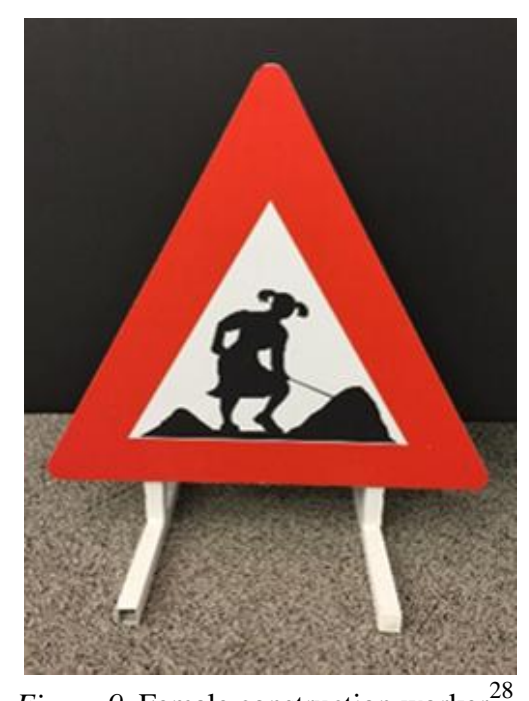

Figure 9. Female construction worker ${ }^{28}$.

The following image "Boys" Toys Logic is intended to shine a sarcastic light on the common belief that boys who play with dolls are allegedly in danger of becoming gay, whereas the "naked beef cake" will allow the child, who has been assigned male, to become a straight, heterosexual boy who is regarded as normal in the stereotypical setting. In this image, the sexual dimension of gender as a continuum is evoked and identified, albeit with a clearly negative connotation in regard to homoerotic desire, connected with gender-stereotypical toys which, in the social dimension of the continuum, assign so-called boys toys whose combative physicality (physical and social dimension of gender as a continuum) guarantee the boy's later heterosexual orientation - supposedly. Here it becomes clear how physicality, plays behavior and sexual orientation/sexual desire, and with them the dimensions of body, behavior and sexual desire in the context of gender as a continuum, are being placed in relation to one another.

\section{'Boys' toys logic}

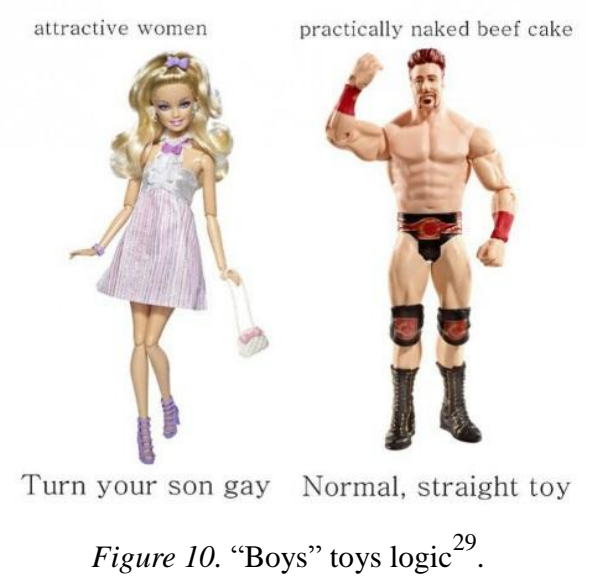

If cartoons go beyond a binary, traditional gender order in regard to sexual orientation, and if topics like transity are also discussed, then the following image Freedom in the (self-)assignment shows two different

\footnotetext{
${ }^{28}$ Ibidem.

${ }^{29}$ http://uberhumor.com/boys-toy-logic, last accessed 03/12/2018.
} 
concepts through the statements of a mother who subscribes to more traditional notions of masculinity and femininity, as depicted on the left side of the image: she forbids her son from playing with dolls and wearing feminine clothes, and accuses the mother who allows her son a free choice in both his toys and his clothing of forcing her child into the role of a girl according to her own wishes. The compulsion to raise her own son according to stereotypical notions of masculinity, and thereby possibly limit his development, is being masked by a sharp and hurtful criticism of an educational behavior which is accepting and allows freedom of choice.

Here as well, in the social dimension of gender, playing with dolls and wearing girls' clothing as a boy is considered an inadmissible manipulation and is rejected by the mother; those persons who open up spaces of experience that transcend gender stereotypes for their children are accused of ascription processes of gender, which are suggested to originate from the unfulfilled wish of having a child of a certain gender. The traditionally heteronormative assignment of a gender based on biomorphological traits is not depicted as a restriction or limitation, but as a pedagogical necessity.

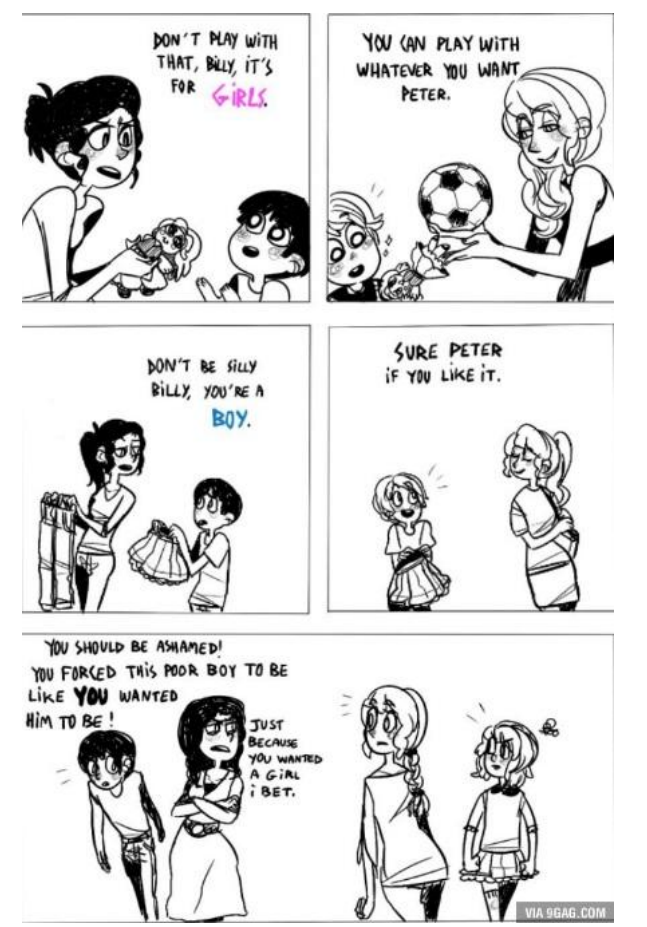

Figure 11. Freedom in the (self-)assignment of gender? ${ }^{30}$.

But even when gender stereotypes are explicitly intended to fade into the background, seemingly resistant remnants remain.

Just in time for March 8, 2016, the International Women's Day, the fashion label Zara released a collection titled Zara Ungendered.

30 "This Is Important", http://9gag,com/gag/a7KOvAq; last accessed on 06/26/2015. 


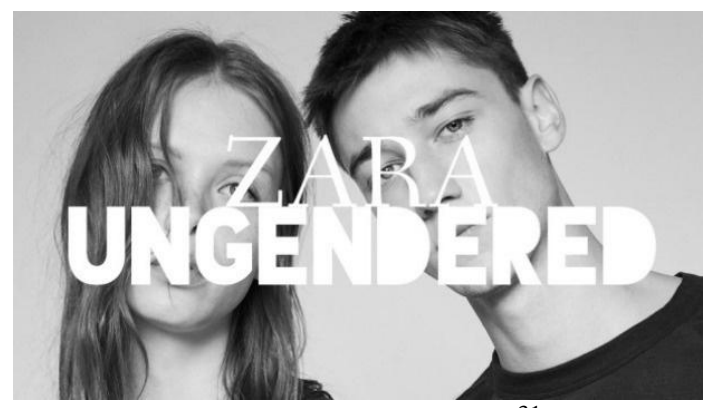

Figure 12. Zara Ungendered ${ }^{31}$.

Closer observation, however, reveals the following:

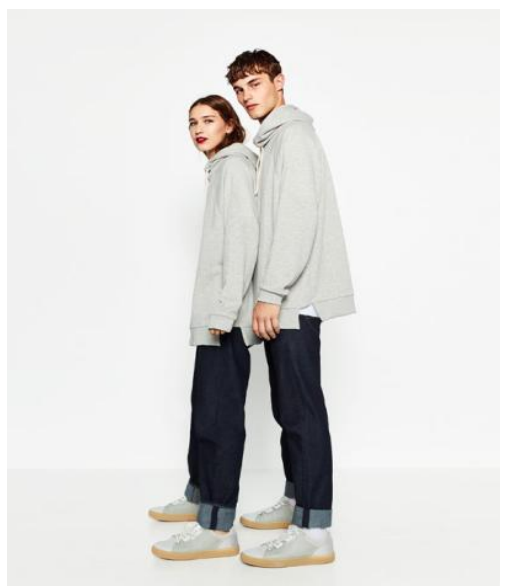

Figure 13. Zara Ungendered ${ }^{32}$.

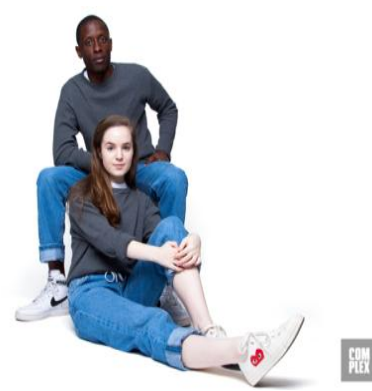

Figure 14. Zara Ungendered ${ }^{33}$.

The articles of clothing are identical, the person on the left side of the image, who is connoted as a woman, has long hair and is also slightly shorter than the short-haired man depicted on the right; even in identical clothing he remains in the role of the protecting man, which in turn corresponds to traditional positionings of femininity and masculinity in the physical, psychological and social dimensions of gender as a continuum.

How gender stereotypes can still show despite a virtually identical presentation can be traced by examining the two books by Sarah Delmege (German translation by Inga Brita-Thiele) with the titles Wie funktioniert das denn für Jungs??? (German: "How It Works for Boys"; English edition: “Just for Boys") and

\footnotetext{
31 https://www.refinery29.com/2016/03/105212/zara-genderless-clothing-line-2016; last accessed on 03/12/2018.

32 Ibidem.

33 Ibidem.
} 
Wie funktioniert das denn für Mädchen??? (German: "How It Works for Girls"; English edition: "Just for Girls"), with the identical subtitle: Das Buch über das Erwachsenwerden (“A book about growing up"). ${ }^{34}$

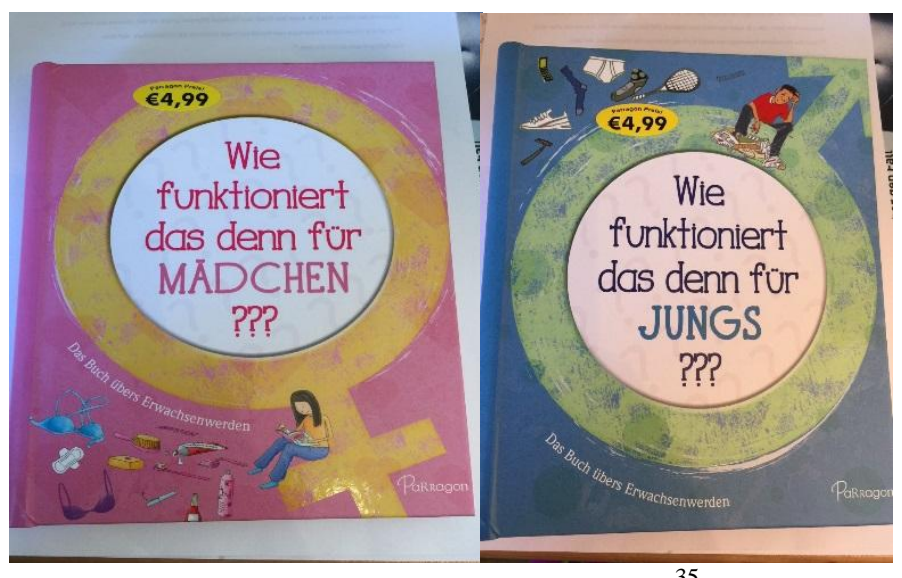

Figure 15. Just for girls-Just for boys ${ }^{35}$.

Even on the covers, the color schemes and positionings, as well as the items attributed to the girl and the boy, are typical for traditional gender roles; we are situated in the social dimension of gender as a continuum. The girl, who is leafing through the book itself, is attributed a bra, a bikini top, a menstrual pad, a tampon, hair-and toothbrushes, toothpaste, nail polish, hair spray and a pink razor; the boy, depicted in a thinker's pose in the upper corner of the illustration, is surrounded by a tennis racket, an electric and a mechanic razor, a pair of underwear, a sock, a shoe and a cellphone. On the respective books' content pages, a girl is depicted reading in an armchair; there is no depiction of a boy on the content page.

\section{First Light at the End of the Tunnel? Pictograms, Signs, Bathrooms}

While traffic signs which indicate a footpath, as a rule, show children walking hand-in-hand with a person who is connoted with biomorphological traits of femininity, ${ }^{36}$ male attendants of children exist as well, as seen on a traffic sign in Esch-Belval, Luxembourg, which shows a child walking hand-in-hand with an accompanying male adult in order to indicate a footpath.

Here, the traditional connotations between the physical and social dimensions on the continuum of gender are being repositioned.

\footnotetext{
${ }^{34}$ Sarah Delmege (n.d.) (translated by Inga Brita-Thiele): Just for Boys/Just for Girls: Bath: Parragon; German Version: Köln: trans texas.

35 Fotos taken on 02/15/2018 by Christel Baltes-Löhr.

36 Vorschriftzeichen 239 as per Addendum 2 to $\$ 41$ StVO;

https://de.wikipedia.org/wiki/Bildtafel_der_Verkehrszeichen_in_der_Bundesrepublik_Deutschland_seit_2013, last accessed on 03/12/2016.
} 


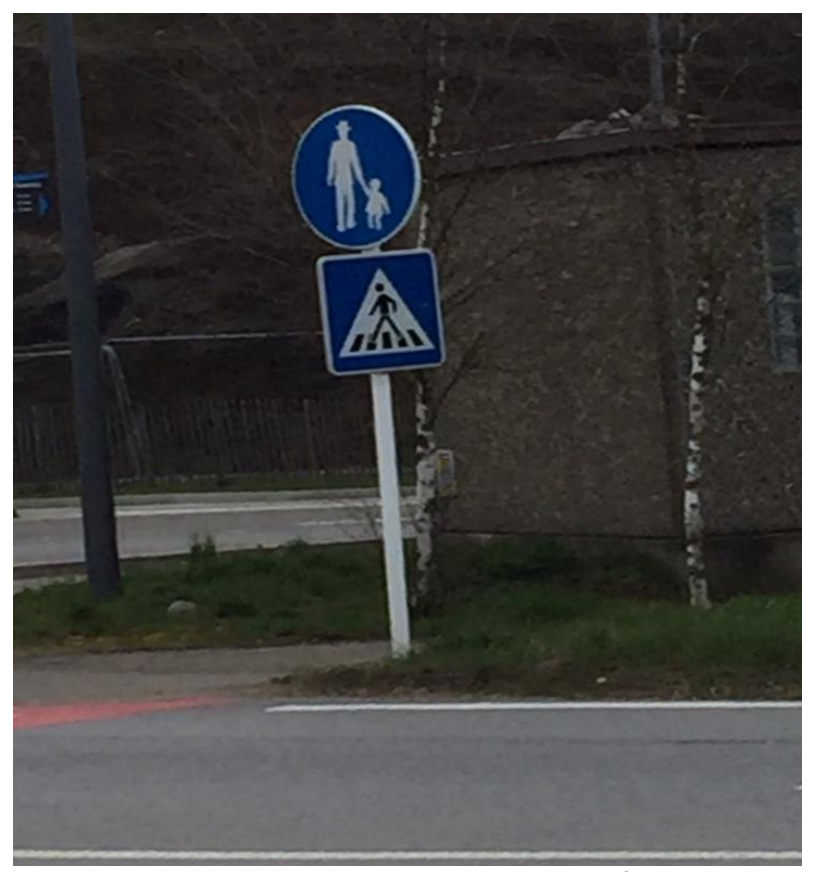

Figure 16. Traffic sign for a footpath ${ }^{37}$.

The same can be said for another sign for a baby changing room in a grocery store in Luxembourg. It is clearly discernible that it does not, like it is still customary in many instances, depict an adult person connoted with stereotypical female physical traits.

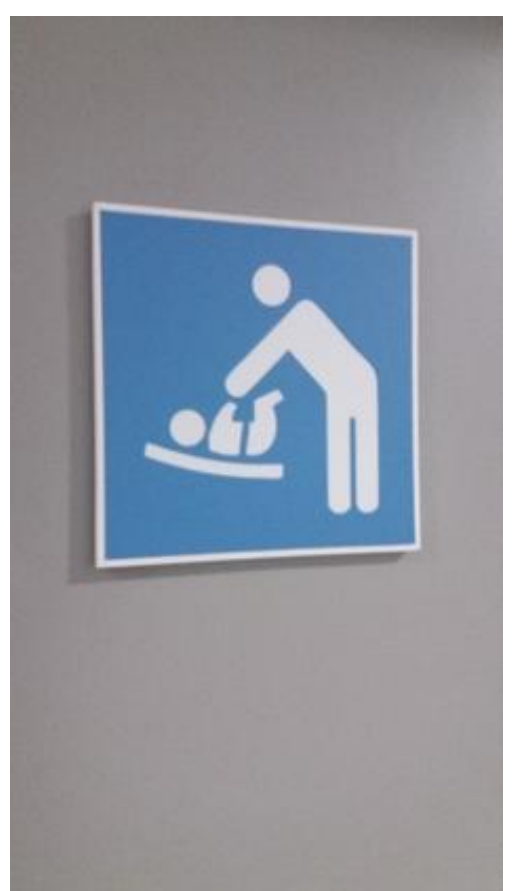

Figure 17. Sign for a baby changing room in a grocery store in Luxembourg ${ }^{38}$.

37 Traffic sign for a footpath in Esch/Belval, Luxembourg; taken on 15/03/2016 by Christel Baltes-Löhr.

${ }^{38}$ Sign for the baby changing room of a grocery store in Luxembourg in the municipality of Redange; taken on 10/03/2016 and provided for this essay courtesy of Bernd Laschet. 
Will signs for public bathrooms, in Luxembourg or anywhere else, look more like those observed in a subway station in Tokyo in January 2018, and will public bathrooms thus more and more lose their function of segregating genders and stabilizing the gender binary? If not only signs are created, but in their wake also bathroom spaces that are not based on a purported bipolarity of gender, and instead are conceptualized as polypolar, then this addresses particularly the physical and social dimensions of gender as a continuum. Physical traits are thus no longer used as a factor of regulation for a specific, in this case a social and spatial, behavior. $^{39}$

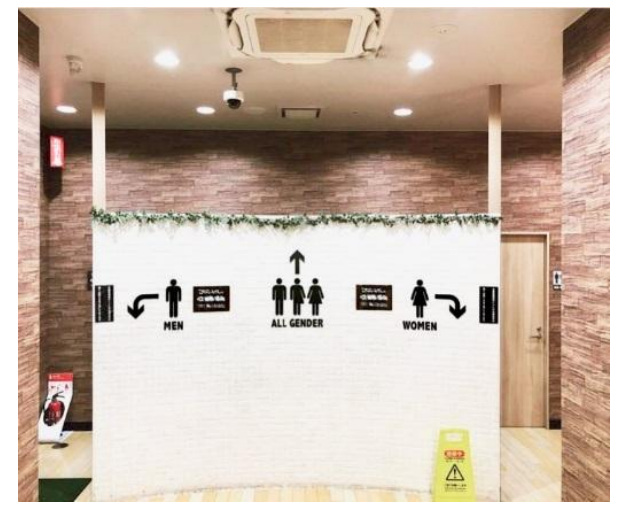

Figure 18. Public bathroom signs in a subway station in Tokyo ${ }^{40}$.

Or will there be more conflict when it comes to the use of public bathrooms, as is the case in the US? In Spring 2016, a heated debate has been sparked about the use of bathrooms in schools and universities. When the US educational and judiciary ministries endeavored to allow so-called transgender students to use the bathroom which corresponds to the gender they identify as, as opposed to the one stated in their birth certificate, ${ }^{41}$ the state of Texas, together with 10 further states, filed a lawsuit against the US government with reference to the protection of privacy. ${ }^{42}$ On March 23, 2016 Pat McCrory, Republican governor of North Carolina, signed the "Public Facilities Privacy \& Security Act", 33 which dictates that transgender persons only use those public facilities (bathrooms, changing rooms, showers etc.) which correspond to the gender stated in their birth certificate; ${ }^{44}$ he stated "I signed this bill because I don't want to allow men to use women's restrooms and changing rooms." 45

This bill has been partly repealed in March $2017 .^{46}$ However, in July 2017 the Texas senate proposed a

\footnotetext{
39 Erving Goffman (1977): “The Arrangement between the Sexes”. In: Theory and Society, vol. 4, no. 3, pp. 301-331.

40 Instagram@korea_japan_travelind, posted on 01/26/2018.

${ }^{41}$ http://www.taz.de/!5307856/; last accessed on 03/12/2018.

42 Alabama, Arizona, Georgia, Louisiana, Maine, Oklahoma, Tennessee, Utah, West Virginia, Wisconsin. Mississippi und Kansas have announced that they will ignore the guidelines of the US authorities. However, protests in Georgia have led to the state exiting out of the lawsuit; http://www.welt.de/print/die_welt/vermischtes/article154627045/Jenseits-von-Mann-und-Frau.html; last accessed on 03/12/2018.

${ }^{43} \mathrm{http} / / /$ www.ncleg.net/Sessions/2015E2/Bills/House/PDF/H2v4.pdf; last accessed on 03/12/2018.

44 Tennessee, Kansas, South Carolina, Minnesota are working on similar policies. In Mississippi, the "Religious Freedom Law" enables churches and other institutions to deny service to homosexuals, or to lay off transgender persons in private businesses with no further reasons than reference to one's religious beliefs.

45 See footnote 43.

46 Jon Herskovitz (2017): “Texas Senate votes to curb transgender access to public bathrooms", https://www.reuters.com/article/us-texas-lgbt/texas-senate-votes-to-curb-transgender-access-to-public-bathrooms-idUSKBN1AB0 37 ; last accessed on 03/12/2018.
} 
bill "to curb transgender access to public bathrooms" $" 47$ with a very similar content, requiring "that all restrooms, showers and locker rooms in public schools and other state and local government facilities 'must be designated for and used only by persons of the same sex as stated on a person's birth certificate,' as opposed to their gender identity." ${ }^{\prime 48}$ Here as well, the promotion of public safety, as well as the protection of particularly vulnerable women and children, is being invoked as an argument for a restriction such as this. The measure would, apart from this, also overturn local ordinances which allow trans persons access to public bathrooms in cities such as Austin, San Antonio and Dallas.

A metaphorical battle for positionings in the physical and social dimensions of gender as a continuum is being fought. When supporters argue for a restrictive use of public bathrooms according to patterns that are traditional, binary and assigned at birth, they assume both an unambiguous assignment of gender according to physical traits in the physical dimension of the continuum, and a life-long validity of this attribution which is marked on the birth certificate, and they thus mark an expected attribution of the choice of public bathroom in the social dimension of gender as a continuum which is in accordance to this record of gender. So-called trans men and trans women would thus be required to use the public bathrooms that do not correspond to their self-attributed gender. So-called trans women and so-called trans men would position themselves differently in the social dimension of gender as a continuum. Restrictions such as this pervert and misuse the laws and institutions hard-won by the women's movements in the US and other countries since the 1960s, which were intended for the protection of women and children against violence, ${ }^{49}$ under the pretense of protecting women and children from sexual assault and violence, to deny trans persons the right to free and autonomous action in their choice of bathroom; particularly trans women, on whom the debate is strongly focused, are depicted as a danger to women due to an affiliation to the male gender which is biologically rooted and assigned to them, whereas trans men are not considered a danger to men in this line of argument. Transity is reduced to the sexual dimension of gender, and trans women are assigned a supposed position on the male side of sexual desire. It is also noteworthy that inter persons are completely excluded from this debate. It is logical to assume that, after more than half a century of women's movements in the Western, Anglo-Saxon world, progressive changes towards a more comprehensive equality, and a connected democratization of societal structures and individual freedoms, are being heavily questioned by politically right-wing conservative as well as reactionary powers not only in the US, but in parts of Europe as well. ${ }^{50}$

\section{More Light at the End of the Tunnel? Fictional Characters and Picture-Books}

A different matter is the depiction of princesses from the point of view of children:

\footnotetext{
47 Ibidem.

48 Ibidem.

49 See for example: Council of Europe (05/21/2011): Convention on preventing and combating violence against women and domestic violence, https://rm.coe.int/168008482e, last accessed: 03/12/2018.

${ }^{50}$ European Union Agency for Fundamental Rights (FRA) (2013): EU LGBT survey: European Union lesbian, gay, bisexual and transgender survey. Luxembourg: Publications Office of the European Union.

European Parliament (2014): EU Roadmap against homophobia and discrimination on grounds of sexual orientation and gender identity. http://www.europarl.europa.eu/sides/getDoc.do?pubRef=-//EP//TEXT+TA+P7-TA-2014-0062+0+DOC+XML+V0//EN; last accessed on 03/12/2018.
} 


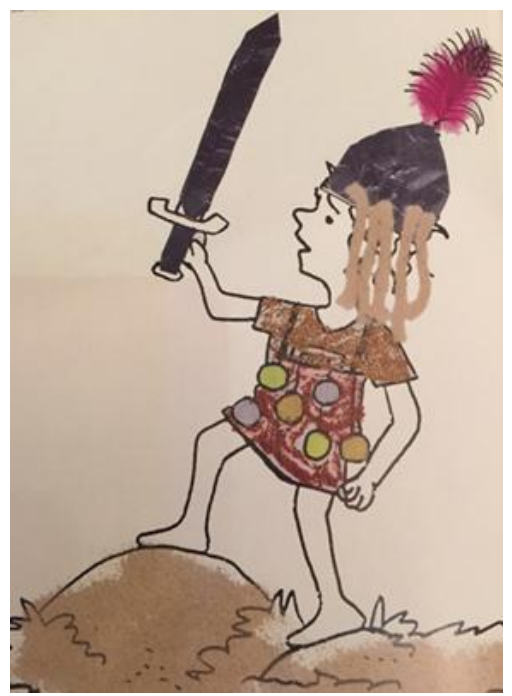

Figure 19. The "Lüsterprinzessin": beautiful, brave and fearful at the same time ${ }^{51}$.

Between 1996 and 2001 the project "Partageons l'égalité—Gläichheet delen—Gleichheit teilen" ("Sharing Equality") took place in the context of the fourth medium- term European Community action program on equal opportunities for women and men under the guidance of the Luxembourg Ministry for Equal Opportunity. As a part of this project, the Sonnentheater in Luxembourg created the fairy tale D'Lüsterprinzessin an de Ritter Schuddereg ("The Princess of Luster and the Knight Shudderman") as a puppet play. Together and with mutual support, the princess and the knight go on adventures, both prove themselves to be brave and strong, and experience both fear and great thirst for adventure. ${ }^{52}$ The fact, that both the princess and the knight are strong and weak, brave and fearful, corresponds to the conclusions of the research of Bronwyn Davies, who states that a simple reversal of gender roles to the point where girls/women are the strong ones and princes the inferior party does not positively resonate with, for example, girls between the ages of 4 and $7 .^{53}$ In The Princess of Luster and the Knight Shudderman it becomes obvious how "as-well-as figures" come close to a de-stereotyping attribution of roles which overcomes gender, all the while, however, the characters are still constricted in a binary corset.

Now, let us take a look at a kindergarten somewhere in Germany in 2015. Here we hear of children, snails and clownfish, mothers, fathers and a teacher. The child Patrick tells the new kindergartner Jill: "'My mom says you're a hermaphrodite, like snails and clownfish.' Jill is silent at first. She doesn't like snails much, they're slow and boring! But of course he knows the clownfish Nemo, and thinks he's really cool!" 54 This text passage is from a children's book about intersexuality. Ursula Rosen published "Jill ist anders" ("Jill is different") in 2015, and the blurb on the back cover reads: "As a child who was born intersex, Jill cannot be placed within the societal norm 'girl or boy'. The kids in kindergarten first search for a solution to this perceived problem, but then realize that Jill is an enrichment of the diversity already existing among the

\footnotetext{
51 Ministerium für Chancengleichheit (2000): D'Lüsterprinzessin an de Ritter Schuddereg. Pädagogisches Material. Luxembourg, p. 64.

52 Ibidem, p. 58.

53 Christel Baltes-Löhr (1999): "Die Lüsterprinzessin und der Ritter Schuddereg”. In: Bundesministerium für Unterricht und kulturelle Angelegenheiten (ed.): Geschlechtssensible Pädagogik in Kindergarten \& Vorschule. Wien: Amedia, pp. 56-60, here p. 59.

${ }^{54}$ Ursula Rosen (2015): Jill ist anders—Ein Kinderbuch zur Intersexualität. Lingen: Salmo, p. 29.
} 
kids. " ${ }^{, 55}$ The illustrated text shows clearly that, for all dimensions of gender as a continuum, binary attributions apply neither to Jill nor to some of the other so-called girls and so-called boys.

These examples should suffice at this point to show how, on the one hand, the concept of gender as a continuum can be applied and used as an analytic instrument, and how on the other hand, actually existing diversities can be located in all their variance.

The following passages will now present realities, practices and changes with a focus on transity and interity.

\section{Ongoing Realities: Surgical Interventions as Attempts at a Production of a Purported Unambiguity}

In spite of all the changes and debates since the late 1960s, and increasingly since the 1990s, to this day surgical interventions are being performed on newborn babies whose penis, clitoris and/or vagina do not conform to standardized measurements, aiming to produce purportedly unambiguous biomorphological sexual characteristics; it is assumed that an unambiguous gender identity on as either a woman or a man of the person thus operated will result from this. With the newborns unable to give their consent, such operations are based on the declarations of consent of parents, who frequently possess little to no information about topics such as intersexuality.

The non-fictional book Mein intersexuelles Kind. weiblich männlich fließend" ("My intersexual child. female male fluid") provides a profound insight into the life of a person born as intersex in 1985 and aligned surgically with the female sex. In 2013, under the pseudonym Clara Morgen, the author reports the life story of her inter child from the perspective of a mother who, by her own account, was not sufficiently informed at the time of the operation. Almost 30 years after the fact, she radically questions her initial assent for the surgeries on her child that were meant to produce a purportedly unambiguous biologically so-called female body. By now, she objects to surgical measures performed on a healthy person in order to produce a purportedly unambiguous gender, without the person in question being able to give their consent, and with this she also objects to the frequently destructive restrictions of the still prevalent binary gender order.

Birgit-Michel Reiter describes what kind of grave and life-threating consequences forced operations may have in the 1999 publication Menschen denken polar, die Natur ist es nicht. Geschlecht als sozialer Code: Intersexualität zwischen Widerstand und Auslöschung ("Human thinking is polarizing, not nature. Gender as a social code: Intersexuality between resistance and extinction"). ${ }^{57}$ Michel Reiter was born in Germany in the late 1960s as a child with a so-called micro penis, a uterus, and the female chromosome set XX. Shortly before his first birthday, his parents consented to the performance of sex-alignment surgeries as well as all following treatments. Not only the constant forced dilation of the neo-vagina with a bougie heavily traumatized Michel Reiter. He describes the operations and treatments as genital mutilation and rape. He recounts that his parents had never spoken to him about the operations and at the age of 29, Michel Reiter finds the following remark while examining his birth certificate at the municipal office in Munich: "By order of the district court of Munich, the following correction is to be recorded: The child is female. The first name Michel is listed as not displayed. The registrar." Michel reclaims the name Michel with the following reasoning: "The fact that my name is Michel again has nothing to do with a desire to be a man. But I have a good feeling about my name

\footnotetext{
55 Ibidem, back cover.

56 Clara Morgen (2013): Mein intersexuelles Kind. Weiblich männlich fließend. Berlin: Transit.

57 Michel Reiter (1999): "Menschen denken polar, die Natur ist es nicht. Geschlecht als sozialer Code: Intersexualität zwischen Widerstand und Auslöschung”. In: Zeitschrift für politische Psychologie, pp. 37-54.
} 
Michel. I think the child with the name Michel was probably happy to come into this world. Birgit, on the other hand, has just been constructed."

Until the current day, trans persons are subjected to protracted procedures and psychiatric assessments before a third party grants them the right to change their marital status, their gender and their first name, a procedure which is in diametral opposition to the human right of self-determination. Even though transity and interity have since the 1990s become subjects of the newly developed Queer Theory, which frequently rejects categorial orders altogether and "opposes those who would regulate identities or establish epistemological claims of priority for those who make claims to certain kinds of identities", ${ }^{58}$ trans and inter persons often remain unmentioned in the approaches adopted by developmental psychology and pedagogy, ${ }^{59}$ are regarded as disruptions as well as disorders, ${ }^{60}$ and in the field of health practice are frequently considered a phenomenon to be dealt with therapeutically. ${ }^{61}$

\section{Contradictions and Tensions}

Concerning trans and inter persons, a blatant contradiction concerning societally accepted medical practices is notable, when on the one hand, surgical procedures on newborns in order to produce a purportedly unambiguous gender identity are still considered normal and are performed in a medical context, so that those parents who are informed about the normality of intersexual forms of existence are forced to assert themselves against surgeons, in order to prevent such procedures being performed on their healthy children. On the other hand, the realization of the desires of adult persons who reject the gender assigned to them at birth, and who seek, for example, hormone treatments or operations in order to biomorphologically produce the gender with which they identify, is still tied to the assent of medical authorities.

Thus we can note that, so far, operations for the production of a binary, bipolar order are being forced on babies and children who are not able to consent, operations for the authorization of which adult persons are forced to subject to medical assessments and protracted administrative procedures. What is shared between these two contradictory customs and legal provisions, however, is that in both cases the human right of self-determination is not respected, and is subordinated to the production of a binary gender system.

A contradiction which is situated in a completely different way is revealed in the fact that transgender and intersex persons are defined as competing groups: "One tension that arises between queer theory and both intersex and transsexual activism centers on the question of sex assignment and the desirability of identity categories. If queer theory is understood, by definition, to oppose all identity claims, including stable sex assignment, then the tension seems strong indeed. ${ }^{, 62}$ What trans persons are in part fighting for, i.e. a life in a male or female gender and correspondingly in the respective gender body, which should, if necessary, be produced with the help of hormone intake or surgery, seems at first glance to be in opposition to inter persons

\footnotetext{
58 Butler, 2004, p. 7.

59 Bettina Abriß (2006): Der Prozess der Entwicklung von Geschlechtsidentität im Kindergarten. Norderstedt: GRIN; Berno Hoffmann (1997): Das sozialisierte Geschlecht. Zur Theorie der Geschlechtersozialisation. Opladen: Leske und Budrich; Vera King (2013): Die Entstehung des Neuen in der Adoleszenz. Individuation, Generativität und Geschlecht in modernisierten Gesellschaften. Wiesbaden: Springer; Helen Sporbert (2009): Geschlechtergerechte Erziehung in der Grundschule. Norderstedt: GRIN.

${ }^{60}$ Uwe Hartmann/Hinnerk Becker (2002): Störung der Geschlechtsidentität. Ursachen, Verlauf, Therapie. Wien: Springer; Brigitte Vetter (2010): Transidentität_ein unordentliches Phänomen. Wenn das Geschlecht nicht zum Bewusstsein passt. Bern: Hans Huber.

61 Verena Averkamp (2012): Jenseits der Geschlechter. Wenn nicht sein kann, was nicht sein darf. Vom Umgang mit Intersexualität. Hamburg: Diplomica.

62 Judith Butler (2004): Precarious Life: The Powers of Mourning and Violence. London/New York: Verso, p. 7.
} 
who often insist on being recognized in the, with respect to the prevalent bipolar gender order, ambiguous situatedness of their gender. In this, the question arises how to include and regard as equally legitimate within a theoretical foundation both the desire for unambiguity and the desire for the recognition of a gender heretofore defined as ambiguous in terms of bipolarity. The figure of Gender as a Continuum seems to offer a release for this tension.

\section{Missing Role Models?}

So-called trans women and so-called trans men are stating by now, often still behind closed blinds, that they potentially would not have undergone hormone treatments and sex reassignment surgeries, if there had been everyday role models and societally accepted examples of persons who, for example, experienced themselves as masculine in a so-called female body, wanted to dress and behave in a more masculine way, without wanting to change their body in the biomorphological or hormonal sense. Such lived normalities would, according to as of yet unpublished accounts of trans' persons in Luxembourg and Germany, have been helpful in, in a way, escaping from still prevalent binary and stereotyping notions of femininity, masculinity etc., and in being able to live a so-called male life in a so-called female body, or any other possible constellations.

Examples from other cultures were first introduced to the general public with the exhibition "She and He. Woman power and male domination in a cultural comparison", which ran from November 25, 1997 to March 8, 1998 in the Rautenstrauch-Joest-Museum für Völkerkunde (Ethnological Museum) in Cologne, Germany. In the exhibition, visitors could learn about Guevedoces, a term used for a group of people living in the Dominican Republic. At birth, they cannot be unambiguously identified as either male or female. Often, a masculinization sets in with puberty, which however does not change the respective person's status of being a Guevedoce, a status which allows some leeway between being a woman and being a man. Another group represented in the exhibition were the Kwolu-Aatmwol of Papua New Guinea who, in expectation of a pubertary masculinization, are raised in a gender-spanning fashion with a tendency towards the male principle and thus develop identities beyond the familiar concepts of femininity and masculinity. As a specific gender they are neither discriminated against nor particularly highly esteemed. Additionally the exhibition highlights the Muxe in Juchitán, Mexico, and the Hijra in India. Now, more than 20 years later, we can see a few major changes in Europe as well, changes that increasingly question a life-long attribution of gender to one person, but that frequently remain attached to binary categories and that focus too much on the sexual orientation of a person in order to assign them to a gender.

\section{Sexual Orientation $\neq$ Gender}

Terms related to "transgender" and "intersex" are frequently mentioned in the same breath as the concept of homosexuality, which reduces transgender and intersex persons to a particular sexual orientation, however it may be defined. Helga Bilden for example speaks of the "great variety of genders and sexualities «and mentions» lesbians, gays, bisexuals, intersex persons, transsexuals, transgender persons" in one breath and without further comment. ${ }^{63}$ Michael Becker, too, bundles “A-, bi-,homo-, inter- and trans-sexuality",64 together without any attempt at differentiation.

\footnotetext{
${ }^{63}$ Helga Bilden (2001): Die Grenzen von Geschlecht überschreiten. In: Anja Tervooren/Jutta Hartmann/Bettina Fritzsche/Andres Schmidt (ed.): Dekonstruktive Pädagogik. Wiesbaden: Springer, pp. 137-147, here p. 144.

${ }^{64}$ Michael Becker (2008): Die Kritik der Queer Theory an der Konstruktion einer bipolaren Geschlechtsidentität. Norderstedt: GRIN, p. 18.
} 
The extent of this entanglement of trans- and intersexuality with homoerotic orientations is also evident in the name of the so-called IDAHO Day. IDAHO Day stands for "International Day against Homophobia" and has been, after continuous and widely-debated extensions, expanded to IDAHO-T, "International Day against Homo- and Trans*-phobia". A similar concept applies to the self-description of non-heterosexual persons in the so-called LGBT community, which refers to the terms "Lesbian, Gay, Bisexual and Transsexual". In this too, there is a current discussion over the expansion of the acronym to LGBT-I, in order to include the group of intersexual persons in all its diversity. Even acronyms like LGBTIQ are by now labels for networks, as for example the network of the federal state Baden-Württemberg in Germany for lesbian, gay, bisexual, trans', intersexual and queer persons. LGBTIQA, or LGBTQIA, today stands for lesbians, gays, bisexuals, transgenders, intersexes, queers (or those questioning their gender identity or sexual orientation), and asexuals (or in some cases allies). All of these expansions are firmly anchored in the aspect of a person's sexual orientation when it comes to the gender the respective person identifies with or to which gender they are attributed. At this point, the question arises how gender, in all its facets of physicality, psychology, social behavior and sexual desire, can be regarded so as not to make one of these dimensions out as the origin of gender. If until the 1960s the biological body was considered to be the purported basis, the binary category for the gender order, then it cannot be called progress if today the sexual orientation is intended to be understood as the fundamental category for attributions assignment of gender.

\section{Gender-Variant, Yet Remaining in a Binary Order?}

How resistant binary, bipolar notions of gender seem to be, is shown by the fact that the Luxembourgian language until the current day maintains a specific term to refer to a girl who acts more like a so-called boy; it speaks of a "verfehlten bouw", a failed boy. ${ }^{65}$ In the introduction to her groundbreaking treatise "The second sex", ${ }^{66}$ Simone de Beauvoir examines the question: what is a woman?, and remarks, among others referring to Thomas von Aquin, ${ }^{67}$ "that the woman was a "failed man', an arbitrary being." medieval scholastics to the often slightly derogatory term "Softie", which arose in German-speaking areas in the 1970s and which referred to a gentle, emotional $\operatorname{man}^{69}$ who did not embody the gender norm of a supposedly always strong, unromantic and rational man that was still prevalent in those times.

In February 2016, photographer Joseph Wolfgang Ohlert published the photographic book Gender as a Spectrum, ${ }^{70}$ and the blurb reads: The persons portrayed in this book "cannot be filed in the usual drawers of 'man and woman'; instead, the subjects have found a position for themselves on the gender spectrum which lies somewhere between these two poles of gender.",71

If we look at prehistoric times, we can come to conclusions about the configuration of gender roles on the basis of concrete pieces of evidence. Brigitte Röder, in the accompanying book to the exhibition with the same name, Ich Mann. Du Frau. Feste Rollen seit Urzeiten? ("I Man. You Woman. Strict Gender Roles Since

${ }^{65}$ Christel Baltes-Löhr 2016b.

66 Simone de Beauvoir (1949): Le Deuxième Sexe. Paris: Gallimard.

67 Ca. 1225-1274; Italy; Medieval, important representative of scholastics https://de.wikipedia.org/wiki/Thomas_von_Aquin.

68 Simone de Beauvoir (1951, 2017): Das andere Geschlecht. Sitte und Sexus der Frau. Reinbek bei Hamburg: Rowohlt, p. 12.

69 Sebastian Scheele (2007): "Schwul leben-heterosexuell lieben. Metrosexualität als homophobe Modernisierung hegemonialer Männlichkeit”. In: Robin Bauer/Josch Hoenes /Volker Woltersdorff (ed.): Unbeschreiblich männlich. Heteronormativitätskritische Perspektiven. Hamburg: Männerschwarm, pp. 213-229, here p. 221; Manuel Borutta/Nina Verheyen (2010) (ed.): Die Präsenz der Gefühle. Bielefeld: transcript, p. 21.

${ }^{70}$ Joseph Wolfgang Ohlert (2016): Gender as a spectrum. Berlin: JWO_Studio.

${ }^{71} \mathrm{http}: / /$ jessica-spirit.de/jenseits-von-mann-und-frau/; last accessed on 12/03/2018. 
Prehistoric Times?"), ${ }^{72}$ which ran between October 2014 and March 2015 in the Archeological Museum Colombischlössle, Freiburg im Breisgau, Germany, shows that notions of gender, clichés, cults of women and men have to be debated anew, just as the everyday life of girls, boys, women and men, and the replacement of gender roles. The supposed unambiguity of the attributions "male hunter" and "female gatherer" is questioned, and Brigitte Röder remarks in the introduction that the finds, especially the Paleolithic figurines, build towards a continuum between the poles "man-woman". ${ }^{73}$ It is worth noting at this point that Röder's analysis remains between the two poles "male" and "female", and that gender roles are indeed being switched in this binary context, but that its aim seems to be the social dimension of gender as a continuum, and thus the behavior of women and men.

\section{Review}

Until now, two things have become clear: the definition of what constitutes gender is still very much connected to binary biomorphological markers of purported female and male bodies, like vagina and penis in newborns, or an elevated or flat chest, broad/narrow shoulders, a broad or narrow pelvis and the extent of facial hair. Physical traits still seem to be considered the basis for the construction of gendered identities, which fundamentally determine the feelings and experiences, the social actions and the sexual desires of humans. Such definitions of gender identities that are based on physical traits as of yet have to be located at one of the poles "female-male", or at a so-called third gender, which has to be moving between the purportedly unambiguous poles "female-male". With the concept of "gender as a continuum", the categories "female", "male", "trans", and "inter" are not reduced to physical traits, trans and inter persons are no longer considered a specific shape of sexual orientation and are no longer reduced to this dimension, are no longer regarded as homogenous units, are no longer confined within the two cornerstones or poles "femininity" and "masculinity". With the concept of "gender as a continuum", transity and interity are thus also no longer to be regarded as purportedly opposite genders.

Similarities and differences are manifest for all genders regarding a) physical sexual traits, the physical dimension of gender, $b$ ) the psychological dimension of gender, which encompasses the self-identification and self-experience as female, male, trans, or inter as well as feelings of belonging, external, and internal assignments to one or several genders, c) the social dimension, which encompasses gender-connoted behavior, and d) the sexual dimension, which focuses on sexual desire, sexual orientations and sexual practices. The figure of the continuum captures these four dimensions and places them in an innovative and interactive relation to one another.

\section{Actual Situation in the Grand Duchy of Luxembourg, the Harvard Business School and at a Wedding}

The founding of the association Rosa Lëtzebuerg in Luxembourg in 1996 constitutes a first, bold questioning of heteronormative gender orders. The association campaigns for the rights of homo- and bisexual persons, ${ }^{74}$ but is now also aimed at trans, inter, and queer persons. ${ }^{75}$ Especially important is the establishment of the gay-lesbian information center Cigale in 2002. In 2009, the first specific advocacy group for trans and inter persons in Luxembourg, the Interessensvertretung Intersex \& Transgender Luxembourg (ITGL) is constituted under the umbrella of Rosa Lëtzebuerg and Cigale. Since 2014, the ITGL acts as an independent

\footnotetext{
${ }^{72}$ Brigitte Röder (2014): Ich Mann. Du Frau. Feste Rollen seit Urzeiten? Freiburg im Breisgau: Rombach.

73 Ibidem, p. 25.

${ }^{74} \mathrm{https} / / /$ lb.wikipedia.org/wiki/Rosa_L\%C3\%ABtzebuerg, last accessed on 01/05/2018.

75 https://de-de.facebook.com/rosa.letzebuerg/, last accessed on 01/05/2018.
} 
organization. An important year regarding the overcoming of heteronormative restrictions is 2015: homosexual couples are able to marry, and in July 2015, a first informal interministerial task force LGBTI $^{76}$ is founded under the coordination of the Luxembourgian ministry for families, encompassing representatives from different ministries, NGOs and the Commission for Human Rights. In 2017, Opinion No. 27 concerning Gender Diversity of the Luxembourg Ethics Committee ${ }^{77}$ is published, in which the binary gender system is fundamentally questioned; in the first of nine recommendations, the government is requested to ensure that sex/gender-related markers personal identification documents are to be deleted, as well as binary restrictions in all legal texts. The Opinion further demands the addition of gender diversity to the constitution (recommendation 2), the abolishment of surgical interventions for the production of sexual characteristics without the concerned person's consent (recommendation 3), the guarantee to respect the equality for all before the law. Discriminations against trans and inter persons or groups are to be anticipated and avoided by the legislature (recommendation 4). Gender diversity should be included into the training of future professionals protected environments created in which persons who are still marginalized can freely express themselves (recommendation 5). The sixth, seventh, and eighth recommendations are aimed at kindergartens, schools and culture, sports , the associative life, the professional sector and research in order to guaranty space and new insights related to all genders. In recommendation 9 the bill No. 7146 related to the modification of sex and first name(s) in the civil registries and amending the Civil Code, which had been present at the time of the passing of the Opinion No. 27 concerning Gender Diversity, is considered by as an important element for the solution to specific situations within a binary gender order (recommendation 9).

The importance of Opinion 27 of the Luxembourg Ethics Committee is underlined when it is considered in connection with by its inclusion in European developments. The resolutions $2048(2015)^{78}$ and $2191(2017)^{79}$ of the European Parliament for the reduction of discriminations against trans and inter persons should be mentioned here, as well as the resolution of the First Senate of the German Federal Constitutional Court from October 12, 2017, whose first principle reads: "The general right to privacy (Art. 2 Abs 1 iVm Art. 1 Abs. 1 GG) protects (...) the gender identity of those, who, on a permanent basis, do not conform to the male or the female gender." ${ }^{, 80}$ In the explanation, the Federal Constitutional Court mentions, among others, the testimonies of the Federal Association Trans*, as well as the Association TransInterQueer, both of which are campaigning for a third gender category, but consider the abolishment of a legally relevant gender entry necessary in the long run: "In the long run, the registration of gender in civil registries should be abolished, because the elicitation of gender as a category in civil status law (...) is only necessary, as long as the different genders are being treated differently before the law." ${ }^{81}$ In the report for Resolution 2191, in sentence 59, the deletion of the gender registration is also mentioned. ${ }^{82}$

\footnotetext{
76 LGBTI stands for Lesbian, Gay, Bisexual, Trans and Intersexual Persons.

${ }_{77} \mathrm{http}: / / \mathrm{cne}$.public.lu/content/dam/cne/fr/publications/avis/avis-27.pdf, last accessed on 01/27/2018.

${ }^{78}$ Discrimination against transgender people in Europe; http://assembly.coe.int/nw/xml/XRef/Xref-DocDetails-en.asp?FileID=21736\&lang=en.

79 Promoting the human rights of and eliminating discrimination against intersex people; http://assembly.coe.int/nw/xml/XRef/Xref-XML2HTML-EN.asp?fileid=24232\&lang=en.

80 https://www.bundesverfassungsgericht.de/SharedDocs/Entscheidungen/DE/2017/10/rs20171010_1bvr201916.html.

81 Ibidem, sentence 32.

82 Promoting the human rights of and eliminating discrimination against intersex people; Author(s): Parliamentary Assembly; Origin. Assembly debate on 12 October 2017 (35th Sitting) (see Doc. 14404, report of the Committee on Equality and Non-Discrimination, rapporteur: Mr Piet De Bruyn).
} 
Similar developments can be observed by a look at Harvard Business School regarding the approach to gender categories in the context of the student application process: between 2006 and early 2008, the online application form showed the category "transgender", next to the options "female" and "male", in the section on gender. From July 2008 until 2010, the indications for "gender" were divided into "female", "male", and "undisclosed". If an applicant selected "undisclosed", they were asked to give more specific details. In 2010, the binary order seemed to be restored at Harvard Business School: applicants were required to choose between the categories of "female" and "male". Since Spring 2016, applications are connected to the creation of a personal account, which does not require a statement in regard to gender. In the application forms accessible after the creation of the account, the question of gender in the category of personal biographical data is marked as optional.

Is the power of the category "gender" diminishing, is the category becoming more fragile? Ex-US Senator from Pennsylvania, Harris Wofford, who at age 90 was married to his partner Matthew Charlton, 50 years his senior, on April 30, 2016: "I will not adhere to a category which is based on the gender of those I love." Wofford was, according to his own statement, happily married to his wife Clare from 1948 until her death in 1996, and has three children. ${ }^{83}$ This desire, which is defined as pansexuality, ${ }^{84}$ is also claimed by pop star Miley Cyrus. With the title "Happy Without Gender" Cyrus professes to not belong to any gender, and to define her sexual orientation as more pansexual. ${ }^{85}$

\section{How Do the Genders View the Relations? Some Empirical Findings}

In three representative studies in the Grand Duchy of Luxembourg and its Greater Region ${ }^{86}$ in $2010,{ }^{87}$ $2013^{88}$ and $2014,{ }^{89} 5,382$ persons were asked for their preference of a gender model. The following models were available choices:

A. The man works full-time, the woman is not employed and she takes care of the household and family.

B. The man works full-time, the woman part-time and she takes care of the household and family.

C. Both partners share work, household and family chores equitably.

D. The woman works full-time, the man part-time and he takes care of the household and family.

E. The woman works full-time, the man is not employed and takes care of the household and family.

The results show the following picture:

\footnotetext{
${ }^{83}$ Trierischer Volksfreund: Liebe ist weder hetero- noch homosexuell, 04/26/2016, p. 28; see also: Harris Wofford (2016): Finding Love Again. This Time With a Man. New York Times, 04/23/2016, http://www.nytimes.com/2016/04/24/opinion/sunday/findinglove-again-this-time-with-a-man.html?_r=0, last accessed on $10 / 15 / 2016$.

${ }^{84}$ For a definition of pansexuality see http://www.gender-glossar.de/de/glossar/item/23-pansexualitaet, last accessed on $10 / 16 / 2016$.

${ }^{85}$ Trierischer Volksfreund: Geschlechtslos glücklich, 10/13/2016, p. 28.

${ }^{86}$ Greater Region is composed of the Grand Duchy of Luxembourg, Wallonia, Saarland, Lorraine, Rhineland-Palatinate and the German-speaking community of Belgium; see: https://en.wikipedia.org/wiki/Greater_Region_of_Luxembourg; last accessed on 11/03/2018.

${ }^{87}$ IPSE (2010) (ed.): Repräsentative Untersuchung der luxemburgischen Wohnbevölkerung im Rahmen des Forschungsprojektes "Doing Identity in Luxemburg. Subjektive Aneignungen—institutionelle Zuschreibungen—sozio-kulturelle Milieus", Bielefeld: transcript.

882011 , in a country-wide study about the compatibility of professional and private life, all educators working in daycare centers for children until the age of four $(n=492)$, as well as the parents of the children in question $(n=1,090)$.

${ }^{89}$ Repräsentative Umfrage der Wohnbevölkerung in Luxemburg und der Grossregion: Christian Wille, Rachel Reckinger, Sonja Kmec, Markus Hesse (2014) (ed.): Räume und Identitäten in Grenzregionen. Politiken-Medien—Subjekte. Bielefeld: transcript.
} 


\begin{tabular}{llllll}
\hline \multirow{2}{*}{ Gender models } & Luxembourg & Parents & Educators & Luxembourg & Greater region \\
& $2010(\%)$ & $2013(\%)$ & $2013(\%)$ & $2014(\%)$ & $2014(\%)$ \\
\hline$n=$ & 1.500 & 492 & 1.090 & 1.021 & 1.279 \\
Traditional housewife model (A) & 12 & 7 & 7 & 8 & 8 \\
Dual burden for the woman(B) & 17 & 33 & 42 & 15 & 16 \\
Egalitarian role distribution (C) & $\mathbf{7 0}$ & $\mathbf{5 6}$ & $\mathbf{4 7}$ & $\mathbf{6 6}$ & $\mathbf{6 3}$ \\
Dual burden for the man (D) & 0,5 & 2 & 2 & 0 & 1 \\
Neo-traditional house-husband & 0,5 & 2 & 2 & 1 & 1 \\
model (E) & & & & \\
\hline
\end{tabular}

Figure 20. Approval ratings for the models A-E in \%; 2010, 2013, and 2014.

The "egalitarian role distribution" is being favored in all studies. The gender models are preferred without the category of gender having a significant impact on the answers of the respondents. Childlessness seems to raise the approval rating for the egalitarian model amongst both those living in partnerships and those living alone. Put differently, as soon as children appear within a relationship, the approval rating for egalitarian partnership and occupational models decreases. ${ }^{90}$ This also explains that the preferences of parents and educators in regards to the "egalitarian role distribution", with 56 and $47 \%$ respectively, are unequivocally higher than for the other four models, but that they are significantly lower than the numbers from the representative polls in 2010 and 2014.

We can thus surmise that the longing for more equality and equal roles is wide-spread, but that in many cases it fails when it comes to its actual implementation in daily life - for mothers and fathers.

Additionally, it should be mentioned that these polls primarily regard the binary gender groups "female" and "male", and that trans and inter persons do not figure prominently. In the representative poll from 2014, the study for the first time featured the category "other" next to those of "female" and "male" in the personal data entry "gender"; this option was made use of by six people, which amounts to $2,6 \%{ }^{91}$ of the 2,300 respondents.

In the course of the study from 2010, the respondents' stands on homosexuality and transity, called transsexuality within the study.

$65 \%$ of all interviewees consider homosexuality and heterosexuality equal. The significantly highest approval rates are found among women (74\%) in comparison to men (57\%). ${ }^{92} 80$ interviews, about the topic of gender among others, were conducted as part of the study. Here, some of the respondents stated that they had never before thought about the topic of homosexuality. In the majority of interviews, respondents confirmed that in Luxembourg, something had changed and that "others" are met with a greater tolerance. However, the increasing official acceptance did not always correspond to unofficial opinions and attitudes. The establishment of a de facto marriage/civil union partnership model for same-sex couples (PACS) in 2004 had not fundamentally changed this: "But the populace still looks askance at it." ${ }^{93}$ Homosexuals are still regarded as "others", as different and not, as possible with the use of the sexual dimension of gender as a continuum, as a normal positioning. This is also partly relevant for the analysis of the results of the interviews, when gay men are described as more sensitive, not only in comparison to other men, but also — and this is noteworthy — in

\footnotetext{
${ }^{90}$ For the year 2014, Statec determined that mothers spend an average of two hours a day more with their children than fathers; http://www.statistiques.public.lu/catalogue-publications/regards/2017/PDF-06-2017.pdf.

91 However, it should be considered that trans persons possibly used the categories "female" or "male".

92 The legislation pertaining to registered partnerships also enabled marriage-like partnerships between same-sex couples. Legislation from 07/09/2004.

93 Personal translation of "Die Bevölkerung schaut aber immer noch schief."
} 
comparison to women. On the one hand, in the physical dimension of gender as a continuum, the biomorphologically male body with homoerotic desires is being compared to so-called men in a heterosexual positioning, but it is also stated in the interviews that this sensitivity is different to that of women. It is also noteworthy that none of those interviewed called themselves homosexual, gay or lesbian. However, some interviewees explicitly called the notion of the binary existing gender normality itself into question, uncertainties are admitted and some concede: "Who knows what is normal, anyway?", In regards to so-called transsexuality, $75 \%$ of those questioned stated that they understand that there are people who do not feel comfortable in their gender role, and 52\% can understand people who wish to change their sex. The responses regarding understanding for discomfort with the gender role show no significant results in respect to nationality, education, occupation and family situation. It is women, those aged between 45 and 49 , who show the highest significant approval rating.

In the interviews, only three of the interviewees reported knowing trans persons. Some stated having acquaintances who know trans persons, others had vaguely heard of them or seen something on television documentaries. One interviewee remembered a female classmate in secondary school who looked like a boy. She mentioned how deeply uncertain everyone at school was at the time, approximately 15 years ago, ${ }^{95}$ about how to approach the girl. Generally, in the interviews, transity was closely associated with homosexuality or with, for instance, breast enlargement. It was often mentioned that, due to the uncertainty about how to approach trans persons, they are frequently subjected to ridicule. Interviewees repeatedly emphasized the importance to immediately consult a psychologist or doctor at the first signs of behavior associated with trans persons. Alongside this tendency to pathologize, there were also calls for tolerance while underlining the fact that it is easier to be tolerant in theory than in practice. During the interviews, we also asked how the interviewees would approach a child who did not feel comfortable in their own gendered body. The answers indicate a lack of knowledge, helplessness as well as insecurity in approaching such a child. Some said that this would perhaps/hopefully only be a passing phase: "If it straightens itself out again, that would be just great." ${ }^{96}$ With regard to adults, however, other interviewees believe that it would be absolutely necessary for those who would like to change their sex to do so, because remaining in a state of such discontent could lead to illness.

The subject of transity is in 2010 still associated with fear, and is regarded as a blow of fate. The further the subject enters into people's private lives, the more of a threat it appears to become. Transity seems to reveal the relevance of identification with one's own gender and if this is called into question, irritations arise.

\section{Next Steps}

In the context of a feasibility analysis, the experiences of trans and inter children and adolescents over the course of their biographical development will be compiled at the University of Luxembourg between September 2018 and October 2019. The results of the biographical interviews will be analyzed by a team comprised of national and international interdisciplinary experts, from the perspective of childhood studies, where the use of the figure "gender as a continuum" is expected to ensure empirically founded results in the analysis of the interviews of how, from the perspective of children and adolescents, the four dimensions of body, feeling, behavior and desire combine and work together when it comes to the construction of gender.

\footnotetext{
94 Personal translation of: "Wer weiß schon, was normal ist?"

95 In 1995

96 Personal translation of: "Wenn es sich wieder einrenkt, ist es eben gut."
} 


\section{Conclusion}

To answer the leading question of this paper, "what are we speaking about when we are speaking about gender?", one answer can be given: we are speaking about us. We are speaking about our body, our feelings and experiences, our behavior and our desire. We are speaking about diverse variations in regards to these four dimensions, about changes over the course of a life, as well as changes from a historical and societal perspective. We are speaking about more than two genders, we are speaking about trans- and intersexuality, which do not have to be positioned between the two purported poles "female" and "male"; we are speaking about so-called women and so-called men, who also do not have to conform to the still pertinent, binary, stereotypical notions of "femininity" and "masculinity". We are speaking about new normalities, which give space to actually experienced diversities and which do not per se understand one gender as 1st, 2nd, 3rd, or 4th. No gender can be regarded as superior to others, but only as a positioning in a specific situation and a specific cultural context. We are speaking about internal and external attributions of gender or its separate dimensions by persons, groups, societies, and we are speaking about similarities and differences when it comes to gender.

And we are speaking about gender as a continuum, when we are speaking about gender, and overcome binary and constructed boundaries between purported gender groups, we create more breathing space for diversity on a conceptual level and can regard gender as non-distinct. Gender is thus more than the structural category for everything and everyone, and instead is to be regarded in connection to other axes of differentiation such as race and class - and will one day possibly become obsolete as a categorical unit of order. Gender does therefore no longer have to be regarded as a "must-have". If we are always speaking about us when we are speaking about gender, then the reverse, that we must always speak about gender when we are speaking about ourselves, is no longer sustainable in this way.

The more the normality of diverse, experienced gender configurations can be portrayed using the figure of the continuum, the less e.g. essentialist assumptions of e.g. the physical basis of gender as everlasting, unambiguous foundation for the attribution to a specific gender group are sustainable. A positioning of persons in discriminatory relations of super- and subordination based on a purportedly unambiguous gender order is increasingly becoming fragile as well.

It is therefore not astonishing when at the end of January 2018 Kerstin Hauernherm, head of marketing of the Beauty Alliance in Bielefeld, Germany, in the Trierischer Volksfreund, a regional paper in Rheinland-Pfalz, is cited from an article with the title "Scent-illating! Finding the Right Perfume" 97 in the rubric "Lifestyle": "It is becoming increasingly obvious that there are barely any differences between perfumes/scents for men and women anymore", 98 or when Annett Heide, on January 24, 2018, in the German weekly newspaper "Die Zeit" reports on Maxi Bauermeister, who "was born with ambiguous gender markers and was forcibly operated to become a girl"," who now lives with the freedom of "being neither man nor woman", 100 and who says: "It is important for society to recognize that there is more than man and woman."

\footnotetext{
${ }^{97}$ Personal translation of: "Das ist dufte! Das richtige Parfüm finden".

98 Trierischer Volksfreund, January 27/28, 2018, p. 40; personal translation of: "Es wird immer deutlicher, dass es kaum noch Unterscheidungen gibt zwischen Damen- und Herrendüften".

99 Personal translation of: "mit uneindeutigen Geschlechtsmerkmalen geboren und zu einem Mädchen zwangsoperiert".

${ }^{100}$ Personal translation of: "weder Mann noch Frau zu sein".

101 http://www.zeit.de/zeit-magazin/leben/2018-01/intersexualitaet-geschlecht-intergeschlechtlichkeit-identitaet; translation of: "Es ist wichtig, dass die Gesellschaft wahrnimmt, dass es mehr gibt als Mann und Frau." 
The diversity of modes of expression and experienced forms of what is regarded as gender is increasing, and can —in its negation and absence as well—be captured and analyzed using the figure of the continuum.

\section{References}

Abriß, B. (2006). Der Prozess der Entwicklung von Geschlechtsidentität im Kindergarten (The process of the developement of gender identity in Kindergarten). Norderstedt: GRIN.

Achutegui, A. (2014). Jeder Tag Weltfrauentag (International Women's Day, Every Day). In Luxemburger Wort, March 8 , p. 3.

Allex, A. (2012). Stop trans*-pathologisierung. Neu-Ulm: AG SPAK.

Averkamp, V. (2012). Jenseits der Geschlechter. Wenn nicht sein kann, was nicht sein darf. Vom Umgang mit Intersexualität (Beyond genders. When what is not supposed to be cannot be. Handling intersexuality). Hamburg: Diplomica.

Baltes-Löhr, C. (1999). Die Lüsterprinzessin und der Ritter Schuddereg (The Princess of Luster and the Knight Shudderman). In Geschlechtssensible Pädagogik in Kindergarten \& Vorschule (Gender-sensitive education in Kindergarten and Preschool) (pp. 56-60). Wien: Amedia.

Baltes-Löhr, C. (2015). Immer wieder Geschlecht-immer wieder anders. Versuch einer Begriffserklärung (Always gender-Always different. An attempt at a definition). In E. Schneider \& C. Baltes-Löhr (Eds.), Normierte Kinder. Effekte der Geschlechternormativität auf Kindheit und Adoleszenz (Normed children. Effects of gender and sex related normativity on childhood and adolescence) (pp. 17-40). Bielefeld: transcript.

Baltes-Löhr, C. (2016a). Geschlecht als Kontinuum—Pluralität als Existenzmuster (Gender as a continuum—Plurality as Pattern of Existence). Gender ca proces continuu-pluralitatea ca model de existență. In Studia Universitatis Babeş-Bolyai. Philologia 4 (vol. 61, pp. 21-36).

Baltes-Löhr, C. (2016b). Die Figur des Kontinuums am Beispiel von Geschlecht und Migration. Ein Erklärungsansatz für Pluralitäten als Existenzmuster (The figure of the continuum exemplified by gender and migration. An approach of explanation to plurality as a pattern of existence)?. In R. Rădulescu \& C. Baltes-Löhr (Eds.), Pluralität als Existenzmuster. Interdisziplinäre Perspektiven auf die deutschsprachige Migrationsliteratur (Plurality as a pattern of existence. Interdisciplinary perspectives on german migration literature) (pp. 9-29). Bielefeld: Transcript.

Baltes-Löhr, C. (2016c). Geschlecht, Migration und Raum als Kontinuum. Versuch einer Begriffsbestimmung (Gender, migration and space as a continuum. Attempt of a definition). In Germanistische Beiträge, 39/2016 (pp. 74-98). Sibiu/Hermannstadt: Universitätsverlag.

Baltes-Löhr, C. (2017). Die Figur des Kontinuums als Analyseraster für Geschlecht in Literatur, Alltag und Geschichte-ein Versuch (The figure of the continuum as an analytical framework for gender in literature, everyday life and history - An attempt). In C. E. Puchianu (Ed.), Konstruktionen von Männlichkeit und Weiblichkeit in der deutschen Kultur, Literatur und Sprache. Reihe Academica. Kronstädter Beiträge zur germanistischen Forschung (Constructions of masculinity and femininity within German culture, literature and language. Series Academica. Kronstadts/Brasovs Contributions to German Studies) (vol. 17, pp. 9-33). Kronstadt/Braşov: Aldus.

Baltes-Löhr, C. (2018a). "Always gender-Always different. An attempt at a definition. In E. Schneider \& C. Baltes-Löhr (Eds.), Normed children. Effects of gender and sex related normativity on childhood and adolescence. Bielefeld: Transcript, Forthcoming.

Baltes-Löhr, C. (2018b). Geschlecht als Kontinuum. Zur Pluralität gelebter Realitäten (Gender as a continuum. About the pluralities of experienced realities). Bielefeld: Transcript, Forthcoming.

Baltes-Löhr, C. (2018c). Geschlecht, Wanderungen, Erinnerungen, Identitätskonstruktionen-ausgeleuchtet mit der Figur des Kontinuums (Gender, migratory movements, memories, constructions of identity-Illuminated with the figure of the continuum). In C. Baltes-Löhr, B. P. Kory, \& G. Sandor (Eds.), Auswanderung und Identität. Erfahrungen von Exil, Flucht und Migration in der deutschsprachigen Literatur (Emigration and identity. Experiences of exile, flight and migration within German literature). Bielefeld: Transcript, Forthcoming.

Becker, M. (2008). Die Kritik der Queer Theory an der Konstruktion einer bipolaren Geschlechtsidentität (The critique of queer theory related to the construction of a bipolar identity of gender gender identity?). Norderstedt: GRIN.

Becker-Schmidt, R. (1993). Geschlechterdifferenz-Geschlechterverhältnis: soziale Dimensionen des Begriffs "Geschlecht" (Gender difference-gender relation: Social dimensions of the concept of "Gender"). Zeitschrift für Frauenforschung (Journal for Women's Studies), 1(2), 37-46. 
Bilden, H. (2001). Die Grenzen von Geschlecht überschreiten (Overstepping the borders of Gender). In A. Tervooren, J. Hartmann, B. Fritzsche, \& A. Schmidt (Eds.), Dekonstruktive Pädagogik (Deconstructive Educational Theory) (pp. 137-147). Wiesbaden: Springer.

Borutta, M., \& Verheyen, N. (2010). Die Präsenz der Gefühle (The presence of emotions). Bielefeld: Transcript.

Butler, J. (1991). Das Unbehagen der Geschlechter (Gender trouble). Frankfurt/Main: Suhrkamp.

Butler, J. (1993). Für ein sorgfältiges Lesen (For a careful reading). In S. Benhabib et al. (Eds.), Der Streit um Differenz (Feminist contentions: A philosophical exchange) (pp. 123-132). Frankfurt/Main: Suhrkamp.

Butler, J. (1995). Körper von Gewicht. Die diskursiven Grenzen des Geschlechts (Bodies that matter: On the discursive limits of sex). Frankfurt/Main: Suhrkamp.

Butler, J. (2004). Precarious life: The powers of mourning and violence. London/New York: Verso.

Commission Nationale d'Éthique. (2017). Opinion 27. Opinion regarding gender diversity. Retrieved from http://cne.public.lu/fr.html

Council of Europe. (05/21/2011). Convention on preventing and combating violence against women and domestic violence. Retrieved from https://rm.coe.int/168008482e

Crenshaw, K. (1991). Mapping the Margins: Intersectionality, Identity Politics, and Violence against Women of Color. Stanford Law Review, 43(6), 1241-1299.

de Beauvoir, S. (1949). Le Deuxième Sexe (The second sex). Paris: Gallimard.

de Beauvoir, S. (1951, 2017). Das andere Geschlecht. Sitte und Sexus der Frau (The other sex. Customs and sexus of the woman). Reinbek bei Hamburg: Rowohlt.

Deleuze, G. (1968). Différence et Répétition (Difference and repetition). Paris: PUF.

Delmege, S. (n.d.). Just for boys/just for girls. Bath: Parragon; German Version: Köln: Trans Texas.

European Parliament. (2014). EU roadmap against homophobia and discrimination on grounds of sexual orientation and gender identity. Retrieved from http://www.europarl.europa.eu/sides/getDoc.do?pubRef=-//EP//TEXT+TA+P7-TA-2014-0062+0+DOC+XML+V0//EN

European Union Agency for Fundamental Rights (FRA). (2013). EU LGBT survey: European Union lesbian, gay, bisexual and transgender survey. Luxembourg: Publications Office of the European Union.

Fassin, É. (2015). Die Kunst, nicht so sehr kategorisiert zu werden. Eine Kritik des Wissens und der Macht des Geschlechts (The art of not being categorized quite so (much). A critique of the knowledge and power of sex). In E. Schneider \& C. Baltes-Löhr (Eds.), Normierte Kinder. Effekte der Geschlechternormativität auf Kindheit und Adoleszenz (Normed children. Effects of gender and sex related normativity on childhood and adolescence) (pp. 87-104). Bielefeld: Transcript.

Fassin, É. (2018). The art of not being categorized quite so (much). A critique of the knowledge and power of sex. In E. Schneider \& C. Baltes-Löhr (Eds.), Normed children. Effects of gender and sex related normativity on childhood and adolescence. Bielefeld: Transcript, Forthcoming.

Goffman, E. (1977). The arrangement between the sexes. Theory and Society, 4(3), 301-331.

Hartmann, U., \& Becker, H. (2002). Störung der Geschlechtsidentität. Ursachen, Verlauf, Therapie (Disruption of gender identity. Causes, progression, therapy). Wien: Springer.

Heide, A. (2018). Intersexualität: Hallo, ich bin die dritte Option (Intersexuality: Hello, I Am the Third Option). Retrieved from http://www.zeit.de/zeit-magazin/leben/2018-01/intersexualitaet-geschlecht-intergeschlechtlichkeit-identitaet

Henke, W., \& Rothe, H. (1998). Biologische Grundlagen der Geschlechtsdifferenzierung (Biological foundations of differentiation between genders). In B. Auffermann \& G. Weniger (Eds.), Frauen-Zeiten—Spuren (Women-Times-Traces) (pp. 43-64). Mettmann: Neanderthal-Museum.

Herskovitz, J. (2017). Texas senate votes to curb transgender access to public bathrooms. Retrieved from https://www.reuters.com/article/us-texas-lgbt/texas-senate-votes-to-curb-transgender-access-to-public-bathrooms-idUSKBN $1 \mathrm{AB} 037$

Hoffmann, B. (1997). Das sozialisierte Geschlecht. Zur Theorie der Geschlechtersozialisation (The socialized gender. On the theory of the socialization of genders). Opladen: Leske und Budrich.

IPSE. (2010). Doing identity in Luxemburg. Subjektive Aneignungen—institutionelle Zuschreibungen—sozio-kulturelle Milieus (Doing identity in Luxembourg. Subjective appropriations_Institutional attributions-Socio-Cultural Milieus). Bielefeld: Transcript.

IPSE. (2012). Katalog zur Ausstellung: iLux. Identitéiten zu Lëtzebuerg/Identités au Luxembourg/Identitäten in Luxemburg. Editorial Team: Sonja Kmec, Gianna Thommes, Luxembourg. 
King, V. (2013). Die Entstehung des Neuen in der Adoleszenz. Individuation, Generativität und Geschlecht in modernisierten Gesellschaften (The emergence of the new in adolescence. Individuation, generativity and gender in modernized societies). Wiesbaden: Springer Fachmedien.

Kitliński, T., \& Leszkowicz, P. (2013). Bipolar. Homophobie und Toleranz in Polen (Bipolar. Homophobia and tolerance in Poland). Osteuropa, 10, 195-239.

Knapp, G. A. (2005). Intersectionality - ein neues Paradigma feministischer Theorie? Zur transatlantischen Reise von "Race, Class, Gender" (Intersectionality - A new paradigm of feminist theory? On the transatlantic journey of race, class, gender). Feministische Studien, 1, 68-81.

Maihofer, A. (1995). Geschlecht als Existenzweise (Gender as a way of existence). Frankfurt/Main: Ulrike Helmer.

Ministerium für Chancengleichheit. (2000). D'Lüsterprinzessin an de Ritter Schuddereg (The Princess of Luster and the Knight Shudderman). In Pädagogisches Material (Educational Material). Luxembourg.

Morgen, C. (2013). Mein intersexuelles Kind. Weiblich männlich fließend (My intersexual child. Female male fluid). Berlin: Transit.

Ohlert, J. W. (2016). Gender as a spectrum. Berlin: JWO_Studio.

Reiter, M. (1999). Menschen denken polar, die Natur ist es nicht. Geschlecht als sozialer Code: Intersexualität zwischen Widerstand und Auslöschung (People think in polar ways, but nature is not. Gender as social code: Intersexuality between resistance and extermination). Zeitschrift für politische Psychologie (Journal for Political Psychology), 37-54.

Röder, B. (2014). Ich Mann. Du Frau. Feste Rollen seit Urzeiten? (I Man. You woman. Strict gender roles since prehistoric times?). Freiburg im Breisgau: Rombach.

Rosen, U. (2015). Jill ist anders-Ein Kinderbuch zur Intersexualität (Jill is different - A children's book about intersexuality). Lingen: Salmo.

Schade, S., Wagner, M., \& Weigel, S. (1994). Zur Einführung (Introduction). In Id. (Ed.), Allegorien und Geschlechterdifferenz (Allegories and gender difference) (pp. 1-7). Cologne: Böhlau.

Scheele, S. (2007). Schwul leben-heterosexuell lieben. Metrosexualität als homophobe Modernisierung hegemonialer Männlichkeit (Gay Life-Heterosexual love. Metrosexuality as a homophobic modernization of hegemonial masculinity). In R. Bauer, J. Hoenes, \& V. Woltersdorff (Eds.), Unbeschreiblich männlich. Heteronormativitätskritische Perspektiven (Indescribably Masculine. Critical perspectives on heteronormativity) (pp. 213-229). Hamburg: Männerschwarm.

Sporbert, H. (2009). Geschlechtergerechte Erziehung in der Grundschule (Gender-appropriate education in primary school). Norderstedt: GRIN.

Streckeisen, U. (1991). Statusübergänge im weiblichen Lebenslauf (Transitions of status in the course of a female life). Frankfurt/Main and New York: Campus.

Trierischer V. (2016a). Liebe ist weder hetero- noch homosexuell (Love is Neither Hetero-Nor Homosexual). 04/26/2016, p. 28.

Trierischer V. (2016b). Geschlechtslos glücklich (Happy without gender). 10/13/2016, p. 28.

Trierischer V. (2018). Das ist dufte! Das richtige Parfüm (Scent-illating! Finding the Right Perfume). 01/27-28/2018, p. 40.

Vetter, B. (2010). Transidentität-ein unordentliches Phänomen. Wenn das Geschlecht nicht zum Bewusstsein passt (Trans-identity - An untidy phenomenon. When gender does not match consciousness). Bern: Hans Huber.

Wille, C., Reckinger, R., Kmec, S., \& Hesse, M. (2014). Räume und Identitäten in Grenzregionen. Politiken-Medien-Subjekte (Spaces and identities in border regions. Policies-Media-Subjects). Bielefeld: Transcript.

Wofford, H. (2016). Finding love again. This time with a man. Retrieved from http://www.nytimes.com/2016/04/24/opinion/sunday/findinglove-again-this-time-with-a-man.html?_r=0.

Zima, P. V. (1997). Moderne/Postmoderne. Gesellschaft, Philosophie, Literatur (Modernity/postmodernity. Society, philosophy, literature). Stuttgart: UTB.

Zirfas, J. (2001). Identitäten und Dekonstruktionen. Pädagogische Überlegungen im Anschluss an Jacques Derrida (Identities and deconstructions. Pedagogical reflections following Jacques Derrida). In A. Tervooren, J. Hartmann, B. Fritzsche, \& A. Schmidt (Eds.), Dekonstruktive Pädagogik (Deconstructive Educational Theory) (pp. 49-64). Wiesbaden: Springer. 